\title{
The pathogenesis, detection, and prevention of Vibrio parahaemolyticus
}

\section{Rongzhi Wang, Yanfang Zhong, Xiaosong Gu, Jun Yuan, Abdullah F. Saeed and Shihua Wang*}

Key Laboratory of Biopesticide and Chemical Biology of Education Ministry and Key Laboratory of Pathogenic Fungi and Mycotoxins of Fujian Province, School of Life Sciences, Fujian Agriculture and Forestry University, Fuzhou, China

\section{Edited by:}

Dongsheng Zhou, Beijing Institute of Microbiology and Epidemiology, China

\section{Reviewed by:}

Adrian Canizalez-Roman, Autonomous University of Sinaloa, Mexico Learn-Han Lee, Monash University Malaysia, Malaysia

*Correspondence:

Shihua Wang, Key Laboratory of Biopesticide and Chemical Biology of Education Ministry and Key Laboratory of Pathogenic Fungi and Mycotoxins of Fujian Province, School of Life Sciences, Fujian Agriculture and Forestry University, Fuzhou 350002, China

e-mail:wshyyl@sina.com
Vibrio parahaemolyticus, a Gram-negative motile bacterium that inhabits marine and estuarine environments throughout the world, is a major food-borne pathogen that causes life-threatening diseases in humans after the consumption of raw or undercooked seafood. The global occurrence of $V$. parahaemolyticus accentuates the importance of investigating its virulence factors and their effects on the human host. This review describes the virulence factors of $V$. parahaemolyticus reported to date, including hemolysin, urease, two type III secretion systems and two type VI secretion systems, which both cause both cytotoxicity in cultured cells and enterotoxicity in animal models. We describe various types of detection methods, based on virulence factors, that are used for quantitative detection of $V$. parahaemolyticus in seafood. We also discuss some useful preventive measures and therapeutic strategies for the diseases mediated by $V$. parahaemolyticus, which can reduce, to some extent, the damage to humans and aquatic animals attributable to $\mathrm{V}$. parahaemolyticus. This review extends our understanding of the pathogenic mechanisms of $V$. parahaemolyticus mediated by virulence factors and the diseases it causes in its human host. It should provide new insights for the diagnosis, treatment, and prevention of $V$. parahaemolyticus infection.
Vibrio parahaemolyticus, a kind of Gram-negative motile bacteria inhabiting marine and estuarine environments throughout the world (Wang et al., 2011a), is a major food-borne pathogen that causes diarrhea primarily after the consumption of raw or undercooked seafood (Bresee et al., 2002; Kawatsu et al., 2006). To ensure its survival in varying environments, $V$. parahaemolyticus has two different types of flagellar systems, allowing it to adapt to constantly changing environments. The polar flagellum is responsible for swimming (Broberg et al., 2011), whereas the lateral flagella are closely associated with the swarmer cell type transformation and biofilm formation (Figure 1). During infection, $V$. parahaemolyticus uses the adhesion factors to bind to the fibronectin and phosphatidic acid on the host cell, thus releasing different effectors and toxins into the cytoplasm, causing cytotoxicity and serious diseases (Gode-Potratz et al., 2011). $V$. parahaemolyticus is a multiserotype bacterium, containing at least 12 different $\mathrm{O}$ antigens and more than seventy different $\mathrm{K}$ antigens in its capsule. Consequently, serotyping has been widely used to detect $V$. parahaemolyticus and to study its pathogenesis (Xu et al., 2014). Among the serotypes, three serotypes (O3:K6, O4:K68, and O1:K untypeable) are extremely virulent and pathogenic to humans, and are regarded as the major agents of food-borne diseases (Jones et al., 2012). To date, the genomes of six strains from these different serotypes have been sequenced: strains RimD221063 and AQ3810 from O3:K6, the strains AN5034, K5030, and Peru-466 from O4:K68, and the strain Vp10329 from O4:K12 (Makino et al., 2003; Broberg et al., 2011; GonzalezEscalona et al., 2011). The first fully sequenced and annotated genome of strain RimD221063 has been used as the reference sequence in cell biological and pathogenetic analysis of numerous clinical and environmental $V$. parahaemolyticus strains (Makino et al., 2003).

\section{DISEASE CAUSED BY V. parahaemolyticus}

In 1950, an first outbreak of disease caused by V. parahaemolyticus in the city of Osaka city of Japan was first reported, with acute gastroenteritis in 272 individuals, 20 of whom died (Fujino et al., 1953; Daniels et al., 2000). Since then, 802 outbreaks of foodborne diseases have been reported in 13 of the coastal provinces of eastern China, causing 17,462 individuals to become ill (Wang et al., 2011a). V. parahaemolyticus (40.1\%) accounted for the greatest number of these outbreaks and cases (Liu et al., 2006; Chao et al., 2010). Similar diseases have also been frequently reported in many countries in Asia, Europe, Africa, and in the Americans (DePaola et al., 2000; Alam et al., 2002; LozanoLeón et al., 2003; Martinez-Urtaza et al., 2005; Su and Liu, 2007; Chao et al., 2009). V. parahaemolyticus infection is also disseminated through open wounds, and often causes septicemia in severe cases (Wang et al., 2012). Recently, V. parahaemolyticus has been reported to be the major agent of acute hepatopancreatic necrosis syndrome afflicting penaeid shrimp, and has seriously damaged the shrimp aquaculture industry (Tran et al., 2013).

The food poisoning caused by $V$. parahaemolyticus usually occurs in summer (from June to October), and is predominantly associated with different kinds of seafood, including crab, shrimp, 


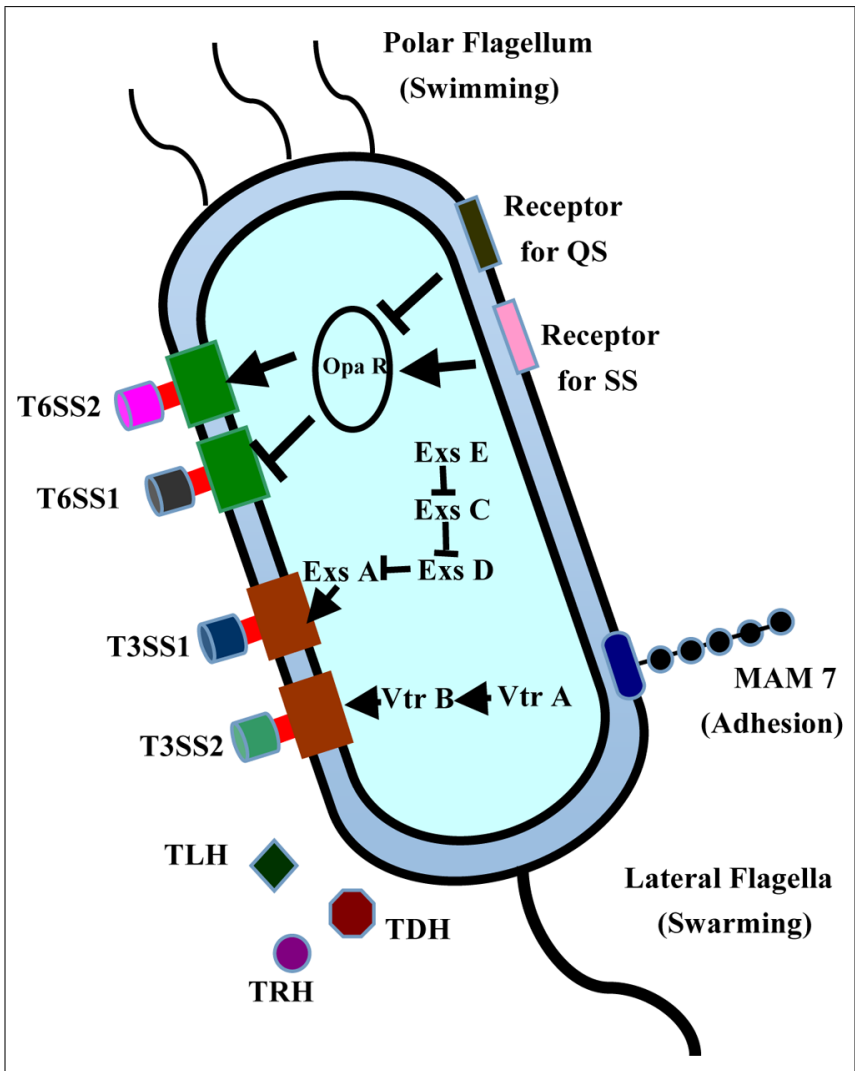

FIGURE 1 | Structures and virulence factors of $V$. parahaemolyticus. V. parahaemolyticus contains two T3SS systems, two T6SS systems, and expresses many toxins, including TLH, TRH, and TDH. MAM7 is responsible for its initial attachment to host cells. This bacterium has two different flagellar systems, allowing it to adapt to changing environments. The polar flagellum is responsible for swimming, whereas the lateral flagella are closely related to the swarmer cell transformation and biofilm formation.

shellfish, lobster, fish, and oysters (Lee et al., 2008; Nakaguchi, 2013; Jones et al., 2014; Cruz et al., 2015; Letchumanan et al., 2015). Among the whole range of seafood, shellfish is regarded as a high-risk food because it is infested with large populations of bacteria, including $V$. parahaemolyticus, to levels higher than those in the surrounding water (Peng et al., 2010; Anonymous, 2012). Once consumers eat undercooked, contaminated seafood, illness is inevitable (Rahimi et al., 2010). The typical clinical symptoms of $V$. parahaemolyticus poisoning are acute dysentery and abdominal pain, accompanied by diarrhea, nausea, vomiting, fever, chills, and water-like stools (Yeung and Boor, 2004; Shimohata and Takahashi, 2010). The feces of patients are mixed with mucus or blood, and their blood pressure decreases dreamily, leading to shock (Broberg etal., 2011). Some severely affected patients become unconsciousness, show recurrent convulsions, become pale or cyanotic, and even death (Nair et al., 2007). The distinct pathological changes in patients include the mild erosion of the jejunum and ileum, gastric inflammation, and internal organ damage (liver, spleen, lung congestion, etc.). To cure $V$. parahaemolyticus infection effectively, common treatment methods include antibiotics and oral rehydration. To avoid intense illness, it is recommended that some subpopulations, including patients suffering severe physical or immunodeficiency diseases, do not consume the seafood (Blake et al., 1979; Hlady and Klontz, 1996).

\section{PATHOGENESIS OF V. parahaemolyticus HEMOLYSIN, UREASE, AND PATHOGENESIS}

Thermostable direct hemolysin (TDH) and TDH-related hemolysin (TRH) are two major virulence factors of $V$. parahaemolyticus, and are closely related to its pathogenicity (Table 1). They have similar hemolytic activity in vitro and cause the lysis of human erythrocytes in excessively saline medium (Sakazaki et al., 1968; Miyamoto et al., 1969; Hondo et al., 1987; Honda et al., 1988). An epidemiological investigation indicated that TDH is one of the major pathogenic factors in V. parahaemolyticus, and is prevalent in almost all (95\%) of clinical isolates. When secreted, it can lyse red blood cells and produces a special hemolysis ring on Wagatsuma blood agar plates (Nishibuchi et al., 1992; Honda and Iida, 1993; Liu, 2003). This is also known as "Kanagawa phenomenon" and is reported to be commonly associated with gastroenteritis (Miyamoto et al., 1969; Joseph et al., 1982). Previous reports have shown that two enzymatic activities of TDH are associated with bacterial pathogenesis. One is a hemolytic activity that is independent of lipid rafts. TDH binds to the membranes of red blood cells or host cells, and forms a pore on the membrane surface, ultimately leading to the permeation of the colloids of red blood cells (Matsuda et al., 2010). The other enzymatic activity is its cytotoxicity, TDH causes cells toxicity and forms a channel in the cell membrane, which induces an increase in the extracellular $\mathrm{Ca}^{2+}$ concentration and $\mathrm{Cl}^{-}$secretion (Matsuda et al., 2010). When the osmotic pressure of the cell exceeds the upper limit for cell self-regulation, pathological and morphological changes were occur in the cell, resulting in cell expansion and even death. Like TDH, TRH causes similar levels of hemolysis in vitro (Takahashi et al., 2000; Ceccarelli et al., 2013).

Thermolabile hemolysin (TLH) is another hemolysin of $V$. parahaemolyticus, encoded by the th gene, and also causes the lysis of red blood cells (Shinoda et al., 1991; McCarthy et al., 1999; Wang et al., 2013b). TLH is expressed by all clinical and environmental strains of V. parahaemolyticus (Bej et al., 1999), and the gene is significantly upregulated under simulated intestinal infection conditions (Gotoh et al., 2010; Table 1). Besides, TLH shows typical lecithin-dependent phospholipase activity, and it also lyses human erythrocytes (Broberg et al., 2011). Therefore, it may play a key role in the process of human infection. Recent, studies have demonstrated that all three types of cells (Hela, Changliver, and RAW264.7 cells) display signs of severe cytotoxicity when treated with the purified TLH protein, and its effects are dose and timedependent (Wang et al., 2012). Therefore, TLH may have similar biological functions similar to these of the TDH and TRH toxins, playing a key role in the V. parahaemolyticus infection. Early studies showed that urease induces the accumulation of intestinal fluid in the rabbit ileal loops test and causes gastrointestinal inflammatory lesions, confirming that urease is an important virulence factor in $\mathrm{trh}^{+}$V. parahaemolyticus strains (Cal and Ni, 1996; Osawa et al., 1996). Urease is encoded by the Uh gene, and is generally involved in the formation of ammonia during the process of infection (Levin, 2006). 
Table 1 | List of known virulence factors of $V$. parahaemolyticus.

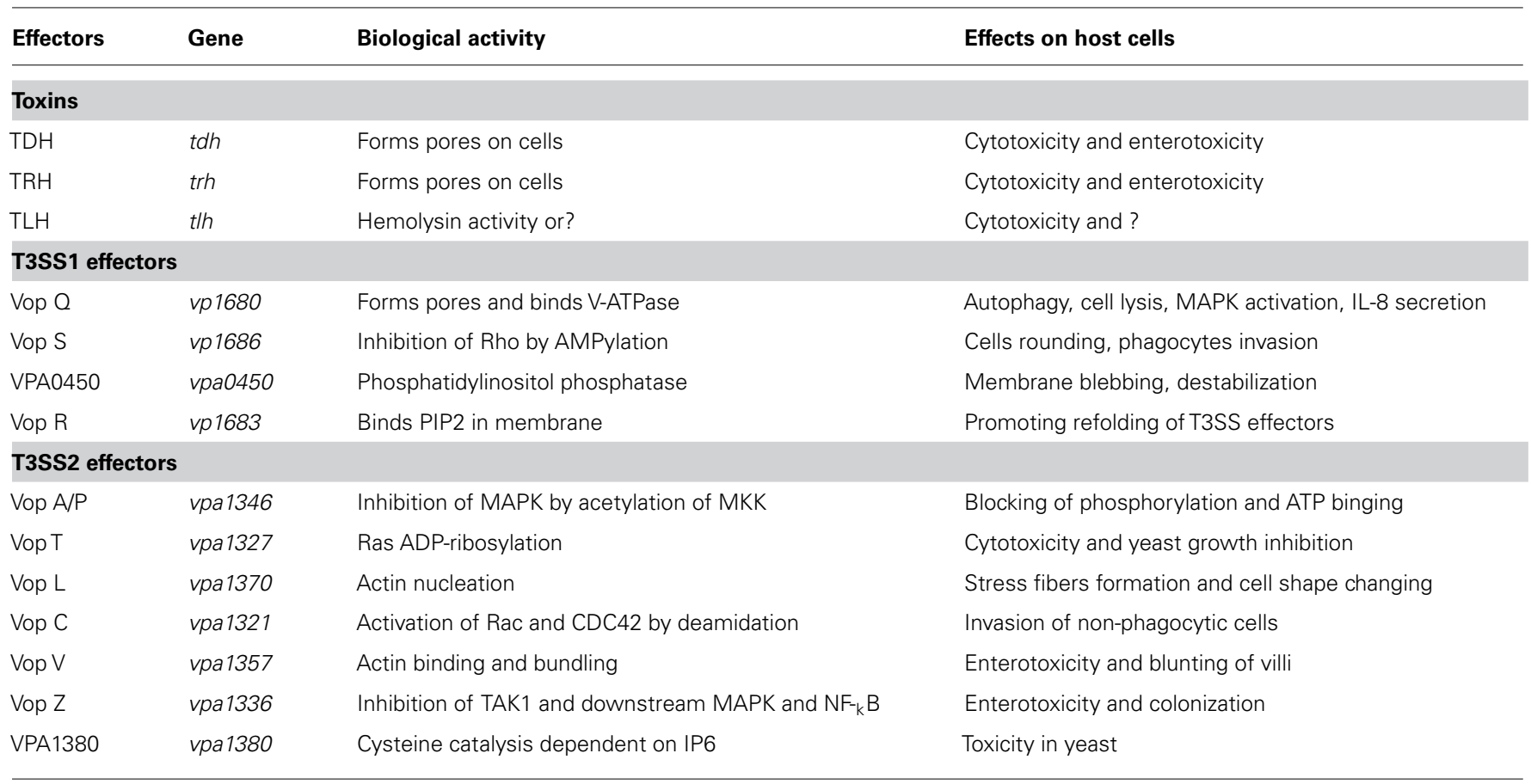

\section{T3SS1 INDUCES AUTOPHAGY AND CYTOTOXICITY}

The type III secretion systems (T3SSs) are transmembrane apparatuses formed by the multicomponent protein complexes (Cornelis, 2006), that allow effectors or virulence proteins to be injected directly into the cytoplasm of the host cell (Dean, 2011; Chatterjee et al., 2013). There are two different T3SS systems in $V$. parahaemolyticus, designated T3SS1 and T3SS2 (Makino et al., 2003). T3SS1 is located on chromosome I, is encoded by the first pathogenicity island, and is present in almost every clinical and environmental $V$. parahaemolyticus strains (Paranjpye et al., 2012). T3SS1 gene expression is regulated by three exoenzyme S synthesis proteins (ExsC, ExsD, and ExsE) and heat-stable nucleoid structuring protein (H-NS; Kodama et al., 2010; Zhou et al., 2010). Several studies have shown that T3SS1 is cytotoxic, causing autophagy, cell rounding, and finally death (Burdette et al., 2008; Hiyoshi et al., 2010; Okada et al., 2010; Ritchie et al., 2012; Zhang and Orth, 2013). To date, four effectors have been determined in T3SS1 (Table 1): Vop Q, Vop S, VPA0450, and Vop R (VP1638), correspondingly (Broberg et al., 2010; Luong etal., 2010; Salomon et al., 2013a; Sreelatha et al., 2013; Figure 2).

The effector Vop Q (Park et al., 2004a) is necessary for the formation of autophagic vesicles in the process of $V$. parahaemolyticus infection (Matsuda et al., 2012). Many researchers have confirmed that the $V$. parahaemolyticus strain in which T3SS1 is deleted can be easily engulfed and degraded by macrophages, causing the apoptosis of the infected cells (Burdette et al., 2009; Sreelatha etal., 2013). These results indicate that T3SS1 effectively inhibits the ability of the host cells to phagocytose $V$. parahaemolyticus (Jegga et al., 2011). Vop Q is also reported to be an activator of the JNK, p38, and MAPK pathways in Caco-2 cells, and interacts with the $\mathrm{C}$ subunit of the vacuolar $\mathrm{H}^{+}$-ATPase (Matlawska-Wasowska et al., 2010; Porta et al., 2011), leading to the secretion of the chemokine interleukin 8 (IL-8; Shimohata et al., 2011).

Vop S, another effector secreted by T3SS1, causes the death of macrophages by inhibiting NF- $\mathrm{B}$ activity. Vop $\mathrm{S}$ contains a Fic domain at its $\mathrm{C}$ terminus, and also prevents actin aggregation and rapid re-aggregation by AMPylating the Rho family GTPases (Casselli et al., 2008; Yarbrough et al., 2009; Luong et al., 2010), resulting in the rounding of the infected cells (Kim and Jo, 2013). This change allows the pathogen to suppress the phagocytosis of infected cells by macrophages (Higa et al., 2013). Vop S also has exerts certain cytotoxicity effects on Hela cells.

VPA0450 is a typical phosphatidylinositide phosphatase, hydrolyzing phosphatidylinositide $(4,5)$-bisphosphate $(\mathrm{PI}(4,5) \mathrm{P} 2)$ to D5 phosphate (PI4P; Krauss and Haucke, 2007). The resulting product, PI4P, disrupts the association between the membrane and the actin cytoskeleton, leading to membrane blebbing (Broberg et al., 2010). VPA0450 induces cell rounding and lysis by destroying the dynamics of the plasma membrane cytoskeleton, and it may play a complementary role with other effectors in the infection process (Broberg et al., 2010).

Vop $\mathrm{R}$ is encoded by the $v p 1683$ gene and is secreted by T3SS1. It also contains a similar phosphoinositide-binding domain (BPD) that is conserved in diverse type III effectors of both plant and animal pathogens (Salomon et al., 2013a). Vop R localizes to the host membrane by its N-terminal domain and specifically binds the phosphoinositide on the host cell. It may also play a key role in promoting the refolding of Type III effectors after their delivery into the host cells (Geissler, 2012; Hicks and Galan, 2013; Salomon et al., 2013a). 


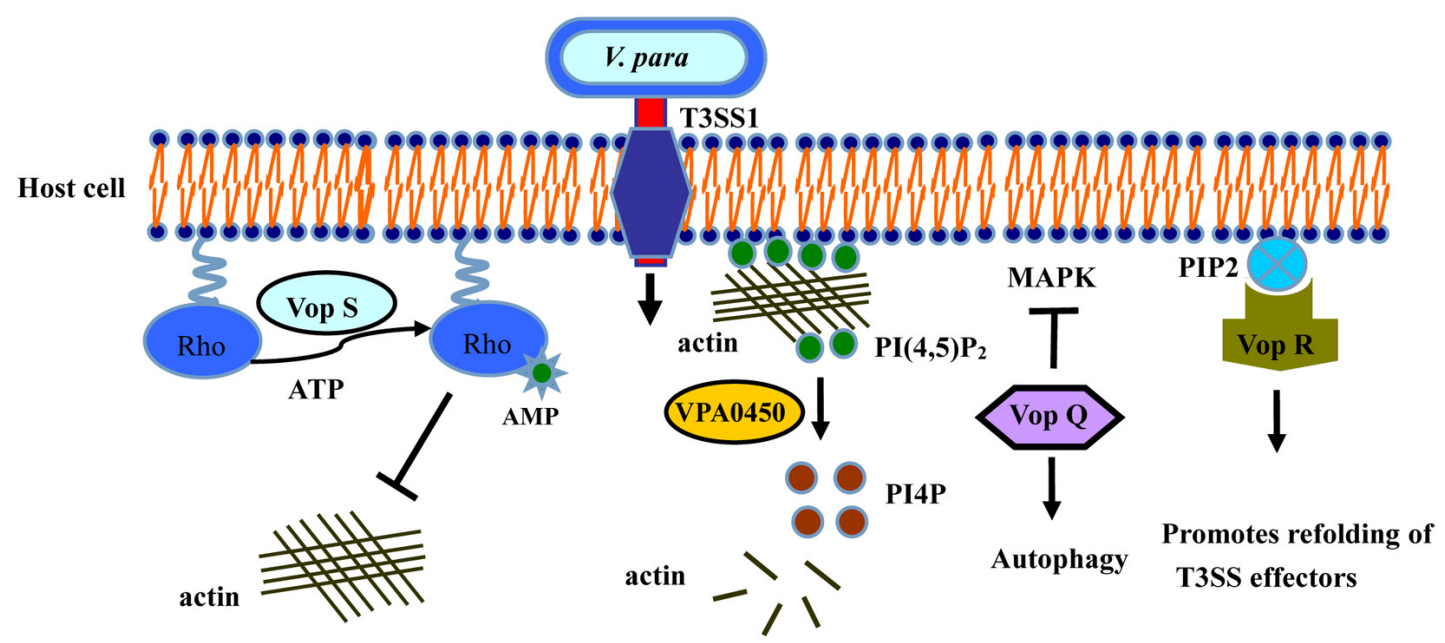

Inhibits actin assembly

Destroys the association between

membrane and actin cytoskeleton

FIGURE 2 | Activities of T3SS1 effectors in cultured intestinal epithelial cells. Vop $\mathrm{Q}$ inhibits the MAPK pathway by acetylating MKK, and Vop S inhibits Rho by AMPylation, leading to cells rounding and phagocytes invasion. VPA0450 hydrolyzes phosphatidylinositide $(4,5)$-bisphosphate
(PI $(4,5)$ P2) to D5 phosphate (PI4P) and disrupts the association between the membrane and the actin cytoskeleton, leading to membrane blebbing. Vop $R$ binds to PIP2 in the membrane, thus promoting the refolding of the T3SS effectors.

\section{T3SS2 MEDIATES ENTEROTOXICITY AND CYTOTOXICITY}

T3SS2, a newly identified type of secretion system, is encoded by a pathogenicity island (VP-PAL) on chromosome II, and is found primarily in clinical isolates (Meador et al., 2007). T3SS2 has been associated with enterotoxicity in the rabbit ileal loop model, infant rabbits and piglets (Makino et al., 2003; Paranjpye et al., 2012), and has also been shown to cause cytotoxicity in intestinal cell lines such as Caco-2 cells and HCT cells (Park et al., 2004b; Hiyoshi et al., 2010; Ritchie et al., 2010; Figure 3). Seven known effectors have so far been identified and characterized in T3SS2 (Table 1): Vop C, Vop T, Vop Z, Vop A/P, Vop V, Vop L, and VPA1380 (Trosky et al., 2004; Kodama et al., 2007; Liverman et al., 2007; Yu et al., 2011; Zhang et al., 2012; Calder et al., 2014).

Vop A/P (VPA1346) is an acetyltransferase with 55\% homology to Yop J of Yersinia spp. (Makino et al., 2003), which blocks the MAPKs signaling pathway by inhibiting the start and biological activity of mitogen-activated protein kinase (Trosky et al., 2004), thereby suppressing cell division via a new mechanism. Vop L (VPA1370) contains three Wiskott Aldrich homology 2 (WH2) domains and a C-terminal domain (VCD; Namgoong et al., 2011; Yu et al., 2011), which generally induces the formation of polarized actin fibers and accelerates the gathering of actin filaments by binding to actin monomers (Liverman et al., 2007). Notably, Vop $\mathrm{L}$ may provide a favorable microenvironment in which bacteria can replicate, thereby enhancing the uptake and invasion of $V$. parahaemolyticus.

Vop $\mathrm{C}$ disturbs the actin network and causes bacterial invasion by deamidating glutamine 61 in both Rac and CDC42, which occurs in their switch regions, resulting in the constitutive activation of the Rho family GTPases (Friebel et al., 2001; Zhang et al., 2012). The actin cytoskeletons of infected cells are further rearranged with the modification of these GTPases, thereby prompting the infected cells to engulf the bacteria (Zhang et al., 2012). Vop $\mathrm{T}$ modifies the small $\mathrm{G}$ protein with ADP-ribose using $\mathrm{NAD}^{+}$as the substrate in vivo and in vitro (Fraylick et al., 2002; Barbieri and Sun, 2004). Vop $\mathrm{T}$ inhibits yeast cell growth and is cytotoxic for Caco-2 and HCT-8 cells (Kodama et al., 2007).

Vop V has long repeat (LR) regions in its $\mathrm{N}$ - and C-terminal domains, composed of three types of repeated sequence units. It predominantly induces the enterotoxicity observed in the rabbit ileal loop model (Hiyoshi et al., 2011), and binds directly to Factin, a polymeric form of actin, leading to the accumulation of F-actin filaments beneath the bacterial microcolonies in Caco-2 cells (Haglund and Welch, 2011). All the above results indicate that F-actin binding is required for the enterotoxicity caused by Vop V (Hiyoshi et al., 2011). However, the molecular mechanism of this enterotoxicity is still unclear, so further investigations are needed for underlying its crucial role during infection.

Vop Z, a novel effector secreted by the T3SS2 system, is responsible for fluid accumulation, cell detachment, and epithelial damage (Zhou et al., 2013). Intestinal colonization by V. parahaemolyticus and fluid accumulation are reduced when Vop $Z$ is deleted (Zhou et al., 2013). Vop Z inhibits the activation of the MAPK and NF- $\kappa B$ signaling pathways by inhibiting the activation of the TAK1 kinase, resulting in a marked lesion, disrupting on the integrity of the tissue (Kajino-Sakamoto et al., 2008; Zhou et al., 2013). Therefore, it plays a critical role in the virulence of $V$. parahaemolyticus.

VPA1380 was recently identified as a critical effector of V. parahaemolyticus translocated by T3SS2 (Hiyoshi et al., 2011). It was detrimental to and exerted a toxic effect on yeast growth when it was expressed as an enhanced green fluorescent protein (eGFP) fusion protein, when yeast was used as a heterologous eukaryotic system (Calder et al., 2014). Bioinformatic analyses revealed 


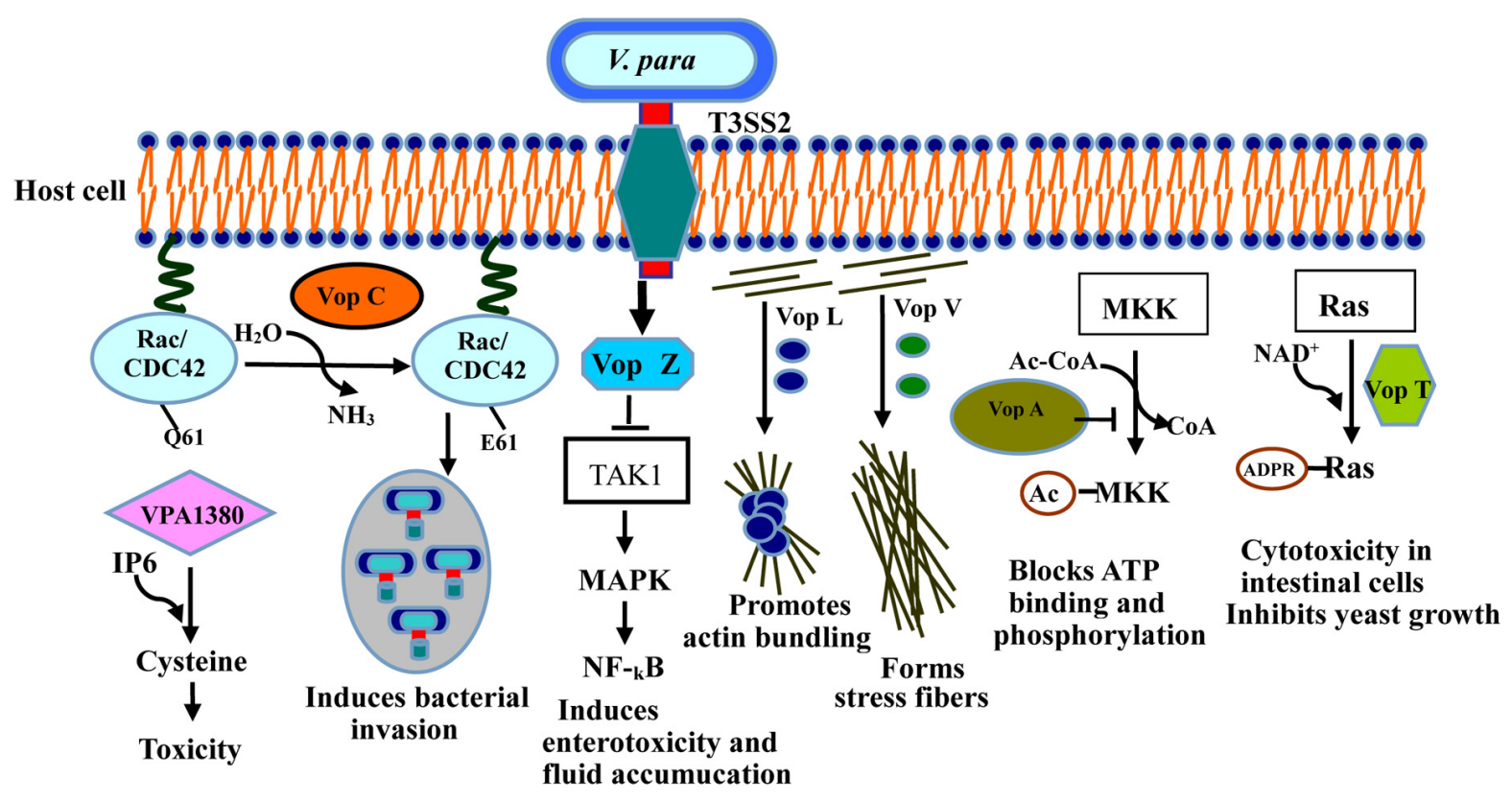

FIGURE 3 | Activities of the T3SS2 effectors in intestinal epithelial cells during infection. Vop $C$ deamidates small GTPases such as Rac and CDC42, inducing bacterial invasion. Vop $L$ dimerizes through its VCD domain, thus promoting actin bundling. Vop A inhibits MAPK by acetylating of MKK. Vop $\vee$ binds directly to F-actin through its long repeat (LR) and
C-terminal domain, forming the stress fibers. Vop T modifies Ras with ADP-ribose, and triggers yeast growth inhibition and cytotoxicity in intestinal cells. Vop Z inhibits the activation of the MAPK and NF-кB pathways by repressing of TAK1 kinase. VPA1380 catalyzes it targeted substrate. that VPA1380 contains several inositol hexakisphosphate (IP6)inducible cysteine protease domains, which are known to occur in large known toxins produced by other bacteria (Prochazkova and Satchell, 2008; Pruitt et al., 2009). VPA1380 is reported to be a typical cysteine protease, catalyzing its targeted substrate (Calder et al., 2014), so VPA1380 is possibly involved in the invasion of host cells by $V$. parahaemolyticus.

\section{T6SS AND PATHOGENESIS}

Recently, a type VI secretion system (T6SS) has been identified, and detected in many Gram-negative bacteria. It is a macromolecular machine consisting of a multicomponent protein complex (Ho et al., 2014). T6SS is responsible for delivering a series of toxic effector proteins into the cytoplasm of eukaryotic cells, allowing the effectors to disrupt the innate immune system and to kill the host cells (Coulthurst, 2013). The T6SS organelle is functionally analogous to T3SS, and may have a critical function in the process of bacterial infection (Salomon et al., 2013a). Interestingly, V. parahaemolyticus contains two different T6SS systems, designated T6SS1 and T6SS2 (Boyd et al., 2008; Yu et al., 2012). T6SS1 is encoded on chromosome I, is predominantly expressed in clinical isolates, and it is most active under warm conditions (O'Boyle and Boyd, 2014). T6SS2 has been found in both clinical and environmental isolates, is encoded on chromosome I, and is active under low-salt conditions (Salomon et al., 2013b). A homology analysis indicated that the T6SSs are present in most different Vibrio species, including V. parahaemolyticus, V. cholerae, $V$. harveyi, and V. alginolyticus (Pukatzki et al., 2006). Recently published medical research articles have reported that both T6SSs are necessary for the adhesion of $V$. parahaemolyticus to cells and are involved in intracellular trafficking and vesicular transport (Boyd etal., 2008; Yu etal., 2012; Salomon et al., 2013b). Only a few effectors of T6SS from $V$. parahaemolyticus have so far been reported. In recent research, two T6SS effectors that mediate its antibacterial activity were identified using proteomic, bioinformatic, and genetic analyses (Salomon et al., 2014). VP1388 is encoded within the T6SS1 gene cluster, whereas VPA1263 is encoded on chromosome II (Salomon et al., 2014). The two effectors contain the conserved MIX motif that is found in proteins with predicted cytotoxic domains, including VgrG and PAARrepeat-containing protein (Pukatzki et al., 2007; Shneider et al., 2013).

\section{DETECTION METHODS BASED ON VIRULENCE FACTORS KANAGAWA TEST}

Thermostable direct hemolysin is a virulence factor that contributes to the formation of a distinct hemolytic ring on blood cells agar plates in high concentrations of salt with D-mannitol as the carbon source, known as the "Kanagawa phenomenon" (KP; Honda and Iida, 1993; Nishibuchi and Kaper, 1995). In the past, the KP has been regarded as an important indicator in the identification of the pathogenic and non-pathogenic V. parahaemolyticus strains (Zhang and Austin, 2005; Ono et al., 2006). However, the detection of $V$. parahaemolyticus based on $\mathrm{KP}$ is time-consuming, labor intensive, and unreliable, and involves the evaluation of large numbers of samples (Park et al., 2004c; Wang et al., 2011b). Therefore, the development of specific, sensitive, and rapid methods to detect this bacterium is crucial for public health. 


\section{PCR DETECTION}

Polymerase chain reaction (PCR) assays are being increasingly used to identify and distinguish specific pathogenic bacteria. Multiplex PCR protocols targeting the toxR, tlh, $t d h$, trh, and fla genes have been developed to detect the total and pathogenic $V$. parahaemolyticus from clinical and environmental samples (Rosec et al., 2009; Izumiya et al., 2011; Wang et al., 2011a; Hossain et al., 2013). Recently, a serogroup-O-specific PCR assay was used to detect and identify $V$. parahaemolyticus pathogens in clinical and environmental samples (Chen et al., 2012). Before 2012, multiplex real-time PCR with different fluorescent probes was used to detect total and pathogenic V. parahaemolyticus in different kinds of seafood (Ward and Bej, 2006; Nordstrom et al., 2007; Tyagi et al., 2009; Robert-Pillot et al., 2010). Garrido used multiplex real-time PCR to detect pathogenic V. parahaemolyticus in water and food samples. The limits of detection for this method were $0.24 \mathrm{CFU} / \mathrm{g}$ for $t d h$, and $0.44 \mathrm{CFU} / \mathrm{g}$ for $t r h 1$, and $0.52 \mathrm{CFU} / \mathrm{g}$ for trh2 (Garrido et al., 2012). A quantitative PCR method combined with propidium monoazide has also been used to quantify the viable $V$. parahaemolyticus cells in raw seafood (Zhu et al., 2012). In general, detection methods based on PCR are quick, high accuracy and sensitivity, but the main disadvantages of that is badly controllability, and the PCR system often need to be optimized to gain the best detection results (Letchumanan et al., 2014).

Loop-mediated isothermal amplification (LAMP) is a specific and highly sensitive technique for DNA amplification under isothermal conditions with the specific primers, and has been widely used to detect pathogenic bacteria in food (Zhao et al., 2011; Qi etal., 2012). LAMP targeting the $t$ lh, $t d h$, or toxR genes of $V$. parahaemolyticus is used for the sensitive and rapid detection of V. parahaemolyticus (Yamazaki et al., 2008; Nemoto et al., 2009; Chen and Ge, 2010). A novel LAMP in situ detection method was reported for the rapid detection of food-borne $V$. parahaemolyticus strains, which has greater specificity and is less time-consumption than regular LAMP and other PCRbased methods (Wang et al., 2013a). Recently, Zeng et al. (2014) developed a novel method that combines the LAMP assay with immunomagnetic separation to detect $V$. parahaemolyticus in raw oysters. The limit of detection was $0.19 \mathrm{CFU} / \mathrm{g}$, thus providing a platform for the comprehensive detection of pathogenic strains using a virulence- gene-specific LAMP assay (Zeng et al., 2014). Although LAMP is an effective and economic method to rapidly detect the pathogenic bacteria at one temperature without the need of cycling, however, similar to PCR, the methods of targeted separation and enrichments severally affected the application of LAMP.

\section{IMMUNOLOGICAL DETECTION}

Immunological methods based on monoclonal antibodies are often used for the rapid detection and quantification of food-borne pathogens in seafood. Sandwich enzyme-linked immunosorbent assays based on monoclonal antibodies directed against TDH, TLH, and TRH have been used to identify these proteins in pathogenic clinical isolates of $V$. parahaemolyticus (Honda etal., 1989, 1990; Kumar etal., 2011; Sakata etal., 2012). However, these monoclonal antibodies do not detect all clinical and environmental $V$. parahaemolyticus strains because they cross-react with other bacteria (Prompamorn et al., 2013). An immunochromatographic assay was developed to detect the TDH hemolysin produced by $V$. parahaemolyticus in enrichment cultures from stool specimens (Kawatsu et al., 2006).

Today, recombinant antibody fragments, such as single-chain variable fragments ( $\mathrm{scFvs}$ ), have become an essential tool for research, diagnostic, and therapeutic purposes (Wang etal., 2014a). In 2012, our group has screened a high affinity scFv antibody successfully against a pathogenic factor TLH of $V$. parahaemolyticus by phage display. The screened scFv-LA3 antibody is specific to TLH antigen, and it is active against Vibrio cells possessing TLH (Wang et al., 2012). Our results indicated that scFv-LA3 recognizes specifically TLH produced by $V$. parahaemolyticus (Wang etal., 2014a), and it can be used as an antibody reagent to detect the TLH producing V. parahaemolyticus strains in seafood (Wang etal., 2012). Compared to the traditional full length Ig G antibody, the sensitivity of immunological method based on scFv is unsatisfactory, and the fact that current scFv antibodies have the poor stability, low solubility, and affinity seriously limits their diagnostic and clinic application. To improve the stability and solubility of scFv antibody, researchers have developed an Skp co-expressed system to express a functional $\mathrm{scF}$ v protein, and the $\mathrm{Skp}$ co-expressed $\mathrm{scF}$ v showed high solubility and binding activity to antigen TLH (Wang et al., 2013b).

\section{OTHERS METHODS}

In addition to the methods discussed above, many detection methods based on biochemistry and biophysics have been used to detect and identify V. parahaemolyticus strains. As early as Su et al. (2005), a chromogenic medium was used for the selective and specific detection of $V$. parahaemolyticus strains. Hayashi et al. (2006), developed a novel method for the early detection of viable and TDH- or TRH-producing $V$. parahaemolyticus in seafood using soft-agar-coated filter combined with multiplex PCR, which identifies seafood samples contaminated with $V$. parahaemolyticus within 2 days. A new enrichment broth containing the bile salt, sodium taurocholate (ST broth) was used for improving the isolation and detection of pathogenic $V$. parahaemolyticus from seafood (Raghunath etal., 2009). A novel light-scattering sensor based solid agar plate has also been used for the real-time detection and identification of $V$. parahaemolyticus, $V$. vulnificus, and V. cholerae colonies (Huff et al., 2012). Dual-color flow cytometry was developed for the simultaneous detection of $V$. parahaemolyticus and Salmonella typhimurium in real samples. In this system, fluorescent quantum dots (QDs) labeled aptamers recognize the two bacterial species, and the sensitivity of detection was increased when QDs nanoparticles was used (Duan et al., 2013). Recently, Xiang et al. (2013) developed a real-time resistance measurement based on four different methods of detection V.parahaemolyticus by targeting the lecithin-dependent hemolysin gene: including LAMP, electrochemical ion bonding (crystal violet and $\mathrm{Mg}^{2+}$ ), real-time monitoring, and derivative analysis. The limit of detection was $10 \mathrm{CFU} / \mathrm{mL}$, and the results revealed that this method is more accurate, sensitive, and specific than culture methods. 


\section{PREVENTION AND CURES BASED ON VIRULENCE FACTORS ANTIBODY NEUTRALIZATION AND INHIBITION}

Given the widespread contamination by $V$. parahaemolyticus and because it is strongly pathogenic to humans, it is very important to prevent and treat the diseases caused by this bacterium. However, to date, no effective measures are available to treat the diseases caused by $V$. parahaemolyticus, and the prospect of developing such therapies is still not good. Excitingly, antibody molecules have become extremely potent candidates for therapeutic applications, and have been developed into an important class of drugs for the treatment of numerous infectious diseases (Hagemeyer et al., 2009). An scFv antibody directed against the pathogenic factor TLH of $V$. parahaemolyticus effectively neutralized the cytotoxicity of $V$. parahaemolyticus TLH, thus exerting a protective effect on various types of TLH-infected cells (Wang et al., 2012). In V. parahaemolyticus, the needle complex is formed by the needle subunit protein (VP1694), which contains only 88 amino acids, and its function only relies on a single polymerized protein (Tamano, 2000; Blocker et al., 2008). The needle subunit may be a useful target protein for screening an effective antibody or inhibitor that can prevent the formation of the needle complex (Davis and Mecsas, 2007). A specific and high-affinity scFv antibody directed against VP1694 (needle subunit) has been prepared, and may play an important role in inhibiting the assembly of T3SS (Wang et al., 2014b). Significantly, the above results showed that the specific and functional $s c F v$ antibodies against target antigens of $V$. parahaemolyticus have been prepared successfully, and it provides a solid foundation for the immunological diagnosis and prevention of the diseases caused by $V$. parahaemolyticus.

\section{INHIBITOR-MEDIATED TARGETED THERAPIES}

Type III secretion systems is conserved among different bacterial pathogens, and it may be an important potential therapeutic target (Gauthier et al., 2005; Mota et al., 2005). Like other Gram-negative pathogenic bacteria, V. parahaemolyticus contains a contact-dependent T3SS, which delivers several effectors into the cytosol of infected host cells (Makino et al., 2003; Park et al., 2004a; Sun et al., 2008; Worrall et al., 2011). The above description shows that T3SS might be a useful target for screening an effective inhibitor that can prevent the formation of the needle complex.

Many small chemical molecules have been shown to block assembly of T3SS, and some compounds broadly inhibit T3SS in many other bacterial pathogens (Izore et al., 2011). A highthroughput assay was developed to screen for a specific transcriptional inhibitor of the virulence factors in enteropathogenic Escherichia coli, to block the promoters of virulence associated factors and thus inhibit their transcription (Gauthier et al., 2005). Sulfonyl amino benzanilides and salicylidene anilides have been shown to inhibit the expression of T3SS- related genes, disrupting different pathways in enteropathogenic E. coli (Kauppi et al., 2003; Gauthier et al., 2005). Benzimidazoles also have also been shown to inhibit the transcription factors LcrF of Yersinia pseudotuberculosis and ExsA of Pseudomonas aeruginosa (Garrity-Ryan et al., 2010; Grier et al., 2010). Salicylidene acylhydrazide and thiazolidinone have been used to repress the formation and assembly of the needle complex, and to block the secretion of effectors in many bacterial pathogens, including Shigella, Yersinia, Chlamydia, and Salmonella spp. (Negrea et al., 2007; Veenendaal et al., 2009; Aiello et al., 2010). Other studies have suggested that thiazolidinones are multifaceted therapeutic agents for inhibiting bacterial infection (Dayam et al., 2006). In summary, the prevention and control of the diseases caused by $V$. parahaemolyticus mainly involve the use of antibiotics, or chemical molecules/drugs, but these inhibitors based on chemical molecules often lead to bacterial drug resistance or environmental residues of drug, resulting in enormous damage to the environment and human health (Pasqualinà et al., 2011; Silva et al., 2014b). Hence, it is very important to develop a feasible measure to improve this dilemma.

\section{BACTERIOPHAGE-BASED THERAPIES}

The increasing prevalence of bacterial antibiotic resistance has prompted a search for candidate agents to replace antibiotics in the effective treatment of bacterial diseases. In recent years, therapies based on bacteriophages have become a topical issue in this field. With the development of phage biology research and genome sequencing, theses methods have been applied to the diagnosis and treatment of bacterial diseases (Laanto et al., 2012; Silva etal., 2014a). A mycobacteriophage delivered by a non-virulent Mycobacterium was reported to effectively kill the $M$. avium and $M$. tuberculosis, and has become a model for phage therapies directed against intracellular bacterial pathogens (Broxmeyer et al., 2002; Peng et al., 2006). The therapeutic efficacy of phage therapies has been demonstrated in many infectious diseases caused by members of the genus Vibrio, including V. vulnificus, V. harveyi, V. parahaemolyticus, and V. anguillarum (Shivu et al., 2007; Crothers-Stomps etal., 2010; Mateus etal., 2014). Phage therapy can protect against experimentally induced vibriosis in the Atlantic salmon, and can effectively prevent mortality during vibriosis of in the brine shrimp and V. anguillarum infections during the production of fish larvae (Higuera et al., 2013; Martinez-Diaz and Hipolito-Morales, 2013; Silva et al., 2014b). Unlike antibiotics or chemical drugs, phage therapies are inexpensive, and more environmentally friendly, and do not induce microbial resistance, suggesting that phage therapy is a suitable alternative treatment for vibriosis in aquaculture industries (Silva et al., 2014b). One of the main challenges in using bacteriophages to control pathogens in seafood is to control the efficacy and safety of phage, and the market acceptance of use of phage. The detailed characterization of phage properties and understanding of phage-host interactions are essential requirements for the successful application of phage-based pathogen control (Tan et al., 2014).

\section{CONTROLS AND PREVENTION}

To reduce the risk of $V$. parahaemolyticus infections associated with seafood consumption, some strategies based on physical and chemical methods have been developed (Su and Liu, 2007). Thermal processing is a common approach to inactivating V.parahaemolyticus residues in seafood. Low-temperature freezing (at $-18^{\circ} \mathrm{C}$ or $\left.-24^{\circ} \mathrm{C}\right)$ or high-temperature treatment $\left(>55^{\circ} \mathrm{C}\right)$ for $10 \mathrm{~min}$ is reported to effectively inactivate or kill $\mathrm{V}$. parahaemolyticus in oysters (Andrews et al., 2000). High-pressure processing (HPP) is another method that has also been used to destroy 
pathogenic microorganisms in seafood, and has been used extensively to inactivate V. parahaemolyticus in oysters (Calik et al., 2002; Cook et al., 2002; He et al., 2002). Irradiation is another important method of eliminating V. parahaemolyticus from oysters. It does not kill the oyster or alter its sensory qualities at low doses, but the safety issues associated with radioactive materials limits its use (Andrews et al., 2003; Jakabi et al., 2003). Similar to the approaches discussed above, chemical reagents have been developed to reduce the bacterial contamination in seafood, including chlorine, electrolyzed oxidizing water and iodophors (Croci et al., 2002; Ren and Su, 2006). However, none of these effectively dislodge V. parahaemolyticus from oysters, and further research is required that focuses on the screening and development of new drugs.

\section{CONCLUSION}

Vibrio parahaemolyticus occurs naturally in marine, estuarine, and coastal environments throughout the world, and is the causative agent of food-borne gastroenteritis (Ceccarelli et al., 2013). The T3SSs are responsible for its cytotoxicity, and play a significant role in the induction of inflammatory chemokines in the host. T3SS1 is essential for systemic infection and the innate immune responses induced during intestinal infection, although the details of the mechanisms are still unclear, and the host targets remain to be determined (O'Boyle and Boyd, 2014). T3SS2 is associated with the enterotoxicity of $V$. parahaemolyticus in mammalian infection models in vivo, and has been reported to cause cytotoxicity in intestinal cell lines (Ham and Orth, 2012). The T6SSs, novel recently identified systems are necessary for the adhesion of $V$. parahaemolyticus to cells and are also involved in intracellular trafficking and vesicular transport. T6SS1 has antibacterial activity under warm conditions, enhancing the environmental fitness of V. parahaemolyticus (Salomon et al., 2013a), but our knowledge of the biological activity of T6SS2 is limited (Salomon et al., 2013a, 2014). Although a number of toxins and effectors associated with the pathogenesis of $V$. parahaemolyticus have been identified and characterized, but the detailed mechanisms of the total effectors of this bacterium, which have evolved to work together, and the distinct functions of individual effectors in causing pathogenicity are yet to be investigated. Further studies should focus on the correlation between T3SS and T6SS, and the non-invasive nature of $V$. parahaemolyticus warrants further investigation. Today, a large number of detection methods based on virulence factors are used for the detection and risk assessment of $V$. parahaemolyticus. However, to reduce the harm attributable to $V$. parahaemolyticus, specific, highly sensitive molecular methods are required to reliably identify and differentiate virulent and avirulent $V$. parahaemolyticus strains. The prevention and treatment of the diseases are still the key outcomes of future research, which should extend our understanding of the precise relationship between the disease in the human host and the pathogenicity of V. Parahaemolyticus. This review article provides insight into the control of the clinical risks posed by this potently virulent bacterium, which is extremely pathogenic to humans, by summarizing the molecular and therapeutic techniques available to future medical and immunological research. Effective control measures that combine novel drugs and targeted therapies must be developed to eradicate the risks posed to human health by this life-threatening disease exclusively.

\section{ACKNOWLEDGMENTS}

This work was supported by Major grant from Science and Technology Project of Fujian Province (2014YZ0001), and Key Project of Science and Technology Department of Fujian Province (2012Y0002), and Young teachers fund of Fujian Agriculture and Forestry University (K13XJJ10A).

\section{REFERENCES}

Aiello, D., Williams, J. D., Majgier-Baranowska, H., Patel, I., Peet, N. P., Huang, J., et al. (2010). Discovery and characterization of inhibitors of Pseudomonas aeruginosa type III secretion. Antimicrob. Agents Chemother. 54, 1988-1999. doi: 10.1128/AAC.01598-09

Alam, M. J., Tomochika, K. I., Miyoshi, S. I., and Shinoda, S. (2002). Environmental investigation of potentially pathogenic Vibrio parahaemolyticus in the Seto-Inland Sea, Japan. FEMS Microbiol. Lett. 208, 83-87. doi: 10.1111/j.15746968.2002.tb11064.x

Andrews, L., Jahncke, M., and Mallikarjunan, K. (2003). Low dose gamma irradiation to reduce pathogenic Vibrio in live oysters (Crassostrea virginica). J. Aquat. Food Prod. Technol. 12, 71-82. doi: 10.1300/J030v12n03_07

Andrews, L. S., Park, D. L., and Chen, Y. P. (2000). Low temperature pasteurization to reduce the risk of Vibrio infections from raw shellstock oysters. Food Addit. Contam. 17, 787-791. doi: 10.1080/026520300415336

Anonymous. (2012). China Statistical Yearbook. Beijing: State Statistical Bureau.

Barbieri, J. T., and Sun, J. (2004). Pseudomonas aeruginosa ExoS and ExoT. Rev. Physiol. Biochem. Pharmacol. 152, 79-92. doi: 10.1007/s10254-004-0031-7

Bej, A. K., Patterson, D. P., Brasher, C. W., Vickery, M. C. L., Jones, D. D., and Kaysner, C. A. (1999). Detection of total and hemolysin-producing Vibrio parahaemolyticus in shellfish using multiplex PCR amplification of $t l, t d h$ and trh. J. Microbiol. Methods 36, 215-225. doi: 10.1016/S0167-7012(99)00037-8

Blake, P. A., Merson, M. H., Weaver, R. E., Hollis, D. G., and Heublein, P. C. (1979). Disease caused by a marine Vibrio. Clin. Characterist. Epidemiol. N. Engl. J. Med. 300, 1-5. doi: 10.1056/NEJM197901043000101

Blocker, A. J., Deane, J. E., Veenendaal, A. K., Roversi, P., Hodgkinson, J. L., Johnson, S., et al. (2008). What's the point of the type III secretion system needle? Proc. Natl. Acad. Sci. U.S.A. 105, 6507-6513. doi: 10.1073/pnas.0708344105

Boyd, E. F., Cohen, A. L., Naughton, L. M., Ussery, D. W., Binnewies, T. T., Stine, T. T., et al. (2008). Molecular analysis of the emergence of pandemic Vibrio parahaemolyticus. BMC Microbiol. 8:110. doi: 10.1186/1471-2180-8-110

Bresee, J. S., Widdowson, M. A., Monroe, S. S., and Glass, R. I. (2002). Food-borne viral gastroenteritis: challenges and opportunities. Clin. Infect. Dis. 35, 748-753. doi: $10.1086 / 342386$

Broberg, C. A., Calder, T. J., and Orth, K. (2011). Vibrio parahaemolyticus cell biology and pathogenicity determinants. Microbes Infect. 13, 992-1001. doi: 10.1016/j.micinf.2011.06.013

Broberg, C. A., Zhang, L., Gonzalez, H., Laskowski-Arce, M. A., and Orth, K. (2010). A Vibrio effector protein is an inositol phosphatase and disrupts host cell membrane integrity. Science 329, 1660-1662. doi: 10.1126/science.1192850

Broxmeyer, L., Sosnowsk, D., Miltner, E., Chacón, O., Wagner, D., McGarvey, J., et al. (2002). Killing of Mycobacterium avium and Mycobacterium tuberculosis by a mycobacteriophage delivered by a nonvirulent Mycobacterium: a model for phage therapy of intracellular bacterial pathogens. J. Infect. Dis. 186, 1155-1160. doi: $10.1086 / 343812$

Burdette, D. L., Seemann, J., and Orth, K. (2009). Vibrio VopQ induces PI3-kinaseindependent autophagy and antagonizes phagocytosis. Mol. Microbiol. 73, 639649. doi: 10.1111/j.1365-2958.2009.06798.x

Burdette, D. L., Yarbrough, M. L., Orvedahl, A., Gilpin, C. J., and Orth, K. (2008). Vibrio parahaemolyticus orchestrates a multifaceted host cell infection by induction of autophagy, cell rounding, and then cell lysis. Proc. Natl. Acad. Sci. U.S.A. 105, 12497-12500. doi: 10.1073/pnas.0802773105

Cal, Y., and Ni, Y. (1996). Purification, characterization, and pathogenicity of urease produced by Vibrio parahaemolyticus. J. Clin. Lab. Anal. 10, 70-73. doi: 10.1002/(SICI)1098-2825(1996)10:2<70::AID-JCLA2>3.0.CO;2-P

Calder, T., Kinch, L. N., Fernandez, J., Salomon, D., Grishin, N. V., and Orth, K. (2014). Vibrio type III effector VPA1380 Is related to the cysteine protease 
domain of large bacterial toxins. PLOS ONE 9:e104387. doi: 10.1371/journal.pone. 0104387

Calik, H., Morrissey, M. T., Reno, P. W., and An, H. (2002). Effect of high pressure processing on Vibrio parahaemolyticus strains in pure culture and Pacific oysters. J. Food Sci. 67, 1506-1510. doi: 10.1111/j.1365-2621.2002.tb10313.x

Casselli, T., Lynch, T., Southward, C. M., Jones, B. W., and Devinney, R. (2008). Vibrio parahaemolyticus inhibition of Rho family GTPase activation requires a functional chromosome I type III secretion system. Infect. Immun. 76, 2202-2211. doi: 10.1128/IAI.01704-07

Ceccarelli, D., Hasan, N. A., Huq, A., and Colwell, R. R. (2013). Distribution and dynamics of epidemic and pandemic Vibrio parahaemolyticus virulence factors. Front. Cell Infect. Microbiol. 3:97. doi: 10.3389/fcimb.2013.00097

Chao, G. X., Jiao, X. N., Zhou, X. H., Wang, F., Yang, Z. Q., Huang, J. L., et al. (2010). Distribution of genes encoding four pathogenicity Islands VPaIs, T6SS, Biofilm, and type I Pilus in food and clinical strains of Vibrio parahaemolyticus in China Foodborne Pathog. Dis. 76, 649-658. doi: 10.1089/fpd.2009.0441

Chao, G., Jiao, X., Zhou, X., Yang, Z., Huang, J., Pan, Z., et al. (2009). Serodiversity, pandemic O3:K6 clone, molecular typing, and antibiotic susceptibility of foodborne and clinical Vibrio parahaemolyticus isolates in Jiangsu, China. Foodborne Pathog. Dis. 6, 1021-1028. doi: 10.1089/fpd.2009.0295

Chatterjee, S., Chaudhury, S., McShan, A. C., Kaur, K., and De Guzman, R. N. (2013). Structure and biophysics of type III secretion in bacteria. Biochemistry 52, 2508-2517. doi: 10.1021/bi400160a

Chen, M. B., Guo, D., Wong, H. C., Zhang, X., Liu, F. X., Chen, H. Y., et al. (2012). Development of O-serogroup specific PCR assay for detection and identification of Vibrio parahaemolyticus. Int. J. Food Microbiol. 159, 122-129. doi 10.1016/j.ijfoodmicro.2012.08.012

Chen, S. Y., and Ge, B. L. (2010). Development of a toxR-based loop-mediated isothermal amplification assay for detecting Vibrio parahaemolyticus. BMC Microbiol. 10:41. doi: 10.1186/1471-2180-10-41

Cook, D. W., O’Leary, P., Hunsucker, J. C., Sloan, E. M., Bowers, J. C., Blodgett, R. J., et al. (2002). Vibrio vulnificus and Vibrio parahaemolyticus in US retail shell oysters: a national survey from June 1998 to July 1999. J. Food Prot. 65, 79-87.

Cornelis, G. R. (2006). The type III secretion injectisome. Nat. Rev. Microbiol. 4, 811-825. doi: 10.1038/nrmicro 1526

Coulthurst, S. J. (2013). The Type VI secretion system a wide spread and versatile cell targeting system. Res. Microbiol. 164, 640-654. doi: 10.1016/j.resmic.2013.03.017

Croci, L., Suffredini, E., Cozzi, L., and Toti, L. (2002). Effects of depuration of molluscs experimentally contaminated with E. coli, Vibrio cholerae $O 1$ and Vibrio parahaemolyticus. J. Appl. Microbiol. 92, 460-465. doi: 10.1046/j.13652672.2002.01548.x

Crothers-Stomps, C., Høj, L., Bourne, D. G., Hall, M. R., and Owens, L. (2010). Isolation of lytic bacteriophage against Vibrio harveyi. J. Appl. Microbiol. 108 1744-1750. doi: 10.1111/j.1365-2672.2009.04578.x

Cruz, C. D., Hedderley, D., and Fletcher, G. C. (2015). Vibrio parahaemolyticus prevalence and distribution in New Zealand shellfish: a long-term study. Appl. Environ. Microbiol. doi: 10.1128/AEM.04020-14 [Epub ahead of print].

Daniels, N. A., Ray, B., Easton, A., Marano, N., Kahn, E., McShan, A. L., et al. (2000). Emergence of a new O3:K6 V. parahaemolyticus serotype in raw oysters. J. Am. Med. Assoc. 284, 1541-1545. doi: 10.1001/jama.284.12.1541

Davis, A. J., and Mecsas, J. (2007). Mutations in the Yersinia pseudotuberculosis type III secretion system needle protein, Ysc F, that specifically abrogate effector translocation into host cells. J. Bacteriol. 189, 83-97. doi: 10.1128/JB.01396-06

Dayam, R., Aiello, F., Deng, J., Wu, Y., Garofalo, A., Chen, X., et al. (2006). Discovery of small molecule integrin alphavbeta3 antagonists as novel anticancer agents. J. Med. Chem. 49, 4526-4534. doi: 10.1021/jm051296s

Dean, P. (2011). Functional domains and motifs of bacterial type III effector proteins and their roles in infection. FEMS Microbiol. Rev. 35, 1100-1125. doi 10.1111/j.1574-6976.2011.00271.x

DePaola, A., Kaysner, C. A., Bowers, J., and Cook, D. W. (2000). Environmental investigations of Vibrio parahaemolyticus in oysters after outbreaks in Washington, Texas, and New York (1997 and 1998). Appl. Environ. Microbiol. 66, 4649-4654. doi: 10.1128/AEM.66.11.4649-4654.2000

Duan, N., Wua, S. J., Yu, Y., Ma, X. Y., Xia, Y., Chen, X. J., et al. (2013). A dual-color flow cytometry protocol for the simultaneous detection of Vibrio parahaemolyticus and Salmonella typhimurium using aptamer conjugated quantum dots as labels. Anal. Chim. Acta 804, 151-158. doi: 10.1016/j.aca.2013.09.047
Fraylick, J. E., Rucks, E. A., Greene, D. M., Vincent, T. S., and Olson, J. C. (2002). Eukaryotic cell determination of Exo S ADP-ribosyltransferase substrate specificity. Biochem. Biophys. Res. Commun. 291, 91-100. doi: 10.1006/bbrc. 2002.6402

Friebel, A., Ilchmann, H., Aepfelbacher, M., Ehrbar, K., Machleidt, W., and Hardt, W. D. (2001). Sop E and Sop E2 from Salmonella typhimurium activate different sets of Rho GTPases of the host cell. J. Biol. Chem. 276, 34035-34040. doi: 10.1074/jbc.M100609200

Fujino, T., Okuno, Y., Nakada, D., Aoyama, A., Mukai, T., and Ueho, T. (1953). On the bacteriological examination of shirasu food poisoning. Med. J. Osaka Univ. 4, 299-304.

Garrido, A., Chapela, M. J., Ferreira, M., Atanassova, M., Fajardo, P., Lago, J., et al. (2012). Development of a multiplex real-time PCR method for pathogenic Vibrio parahaemolyticus detection ( $t d h^{+}$and $\left.t r h^{+}\right)$. Food Control. 24, 128-135. doi: 10.1016/j.foodcont.2011.09.015

Garrity-Ryan, L. K., Kim, O. K., Balada-Llasat, J. M., Bartlett, V. J., Verma, A. K., Fisher, M. L., et al. (2010). Small molecule Inhibitors of LcrF, a Yersinia pseudotuberculosis transcription factor, attenuate virulence and limit infection in a murine pneumonia model. Infect. Immun. 78, 4683-4690. doi: 10.1128/IAI.01305-09

Gauthier, A., Robertson, M. L., Lowden, M., Ibarra, J. A., Puente, J. L., and Finlay, B. B. (2005). Transcriptional inhibitor of virulence factors in enteropathogenic Escherichia coli. Antimicrob. Agents Chemother. 49, 4101-4109. doi: 10.1128/AAC.49.10.4101-4109.2005

Geissler, B. (2012). Bacterial toxin effector-membrane targeting: outside in, then back again. Front. Cell Infect. Microbiol. 2:75. doi: 10.3389/fcimb.2012.00075

Gode-Potratz, C. J., Kustusch, R. J., Breheny, P. J., Weiss, D. S., and McCarter, L. L. (2011). Surface sensing in Vibrio parahaemolyticus triggers a programme of gene expression that promotes colonization and virulence. Mol. Microbiol. 79, 240-263. doi: 10.1111/j.1365-2958.2010.07445.x

Gonzalez-Escalona, N., Strain, E. A., De Jesus, A. J., Jones, J. L., and Depaola, A. (2011). Genome sequence of a clinical O4:K12 serotype Vibrio parahaemolyticus strain 10329. J. Bacteriol. 193, 3405-3406. doi: 10.1128/JB.05044-11

Gotoh, K., Kodama, T., Hiyoshi, H., Izutsu, K., Park, K.-S., Dryselius, R., et al. (2010). Bile acid-induced virulence gene expression of Vibrio parahaemolyticus reveals a novel therapeutic potential for bile acid sequestrants. PLOS ONE 5:e13365. doi: 10.1371/journal.pone.0013365

Grier, M. C., Garrity-Ryan, L. K., Bartlett, V. J., Klausner, K. A., Donovan, P. J., Dudley, C., et al. (2010). N-Hydroxybenzimidazole inhibitors of ExsA MAR transcription factor in Pseudomonas aeruginosa: in vitro anti-virulence activity and metabolic stability. Bioorg. Med. Chem. Lett. 20, 3380-3383. doi: 10.1016/j.bmcl.2010.04.014

Hagemeyer, C. E., Von Zur Muhlen. C., von Elverfeldt, T., and Peter, K. (2009). Single-chain antibodies as diagnostic tools and therapeutic agents. J. Thromb. Haemost. 101, 1012-1019. doi: 10.1160/TH08-12-0816

Haglund, C. M., and Welch, M. D. (2011). Pathogens and polymers: microbe-host interactions illuminate the cytoskeleton. J. Cell Biol. 195, 7-17. doi: 10.1083/jcb. 201103148

Ham, H., and Orth, K. (2012). The role of type III secretion system 2 in Vibrio parahaemolyticus pathogenicity. J. Microbiol. 50, 719-725. doi: 10.1007/s12275012-2550-2

Hayashi, S., Okura, M., and Osawa, R. (2006). Soft-agar-coated filter method for early detection of viable and thermostable direct hemolysin (TDH)- or TDHrelated hemolysin-producing Vibrio parahaemolyticus in seafood. Appl. Environ. Microbiol. 72, 4576-4582. doi: 10.1128/AEM.02646-05

He, H., Adams, R. M., Farkas, D. F., and Morrissey, M. T. (2002). Use of high pressure processing for oyster shucking and shelf-life extension. J. Food Sci. 67, 640-644. doi: 10.1111/j.1365-2621.2002.tb10652.x

Hicks, S. W., and Galan, J. E. (2013). Exploitation of eukaryotic subcellular targeting mechanisms by bacterial effectors. Nat. Rev. Microbiol. 11, 316-326. doi: 10.1038/nrmicro3009

Higa, N., Toma, C., Koizumi, Y., Nakasone, N., Nohara, T., Masumoto, J., et al. (2013). Vibrio parahaemolyticus effector proteins suppress inflammasome activation by interfering with host autophagy signaling. PLoS Pathog. 9:e1003142. doi: 10.1371 / journal.ppat. 1003142

Higuera, G., Bastias, R., Tsertsvadze, G., Romero, J., and Espejo, R. T. (2013). Recently discovered Vibrio anguillarum phages can protect against experimentally induced vibriosis in Atlantic salmon, Salmo salar. Aquaculture 395, 128-133. doi: 10.1016/j.aquaculture.2013.02.013 
Hiyoshi, H., Kodama, T., Iida, T., and Honda, T. (2010). Contribution of Vibrio parahaemolyticus virulence factors to cytotoxicity, enterotoxicity, and lethality in mice. Infect. Immun. 78, 1772-1780. doi: 10.1128/IAI.01051-09

Hiyoshi, H., Kodama, T., Saito, K., Gotoh, K., Matsuda, S., Akeda,Y., et al. (2011). Vop V, an F-actin binding type III secretion effector, is required for Vibrio parahaemolyticus induced enterotoxicity. Cell Host Microbe 10, 401-409. doi: 10.1016/ j.chom.2011.08.014

Hlady, W. G., and Klontz, K. C. (1996). The epidemiology of Vibrio infections in Florida, 1981-1993. J. Infect. Dis. 173, 1176-1183. doi: 10.1093/infdis/173.5.1176

Ho, B. T., Dong, T. G., and Mekalanos, J. J. (2014). A view to a kill: the bacterial type VI secretion system. Cell Host Microbe 15, 9-21. doi: 10.1016/j.chom.2013.11.008

Honda, T., and Iida, T. (1993). The pathogenicity of Vibrio parahaemolyticus and the role of the thermostable direct heamolysin and related heamolysins. Rev. Med. Microbiol. 4, 106-113. doi: 10.1097/00013542-199304000-00006

Honda, T., Ni, Y. X., and Miwatani, T. (1988). Purification and characterization of a hemolysin produced by a clinical isolate of Kanagawa phenomenon negative Vibrio parahaemolyticus and related to the thermostable direct hemolysin. Infect. Immun. 56, 961-965.

Honda, T., Ni, Y. X., and Miwatani, T. (1990). Production of monoclonal antibodies against haemolysin (Vp-TRH) produced by Vibrio parahaemolyticus. FEMS Microbiol. Lett. 56, 167-170. doi: 10.1111/j.1574-6968.1990.tb04143.x

Honda, T., Ni, Y., Yoh, M., and Miwatani, T. (1989). Production of monoclonal antibodies against thermostable direct haemolysin of Vibrio parahaemolyticus and application of the monoclonal antibodies for enzyme link immunosorbent assay. Med. Microbiol. Immunol. 178, 245-253. doi: 10.1007/BF00191059

Hondo, S., Goto, I., Minematsu, I., Ikeda, N., Asano, N., Ishibashi, M., et al. (1987). Gastroenteritis due to Kanagawa negative Vibrio parahaemolyticus. Lancet 1,331332. doi: 10.1016/S0140-6736(87)92062-9

Hossain, M. T., Kim, Y. O., and Kong, I. S. (2013). Multiplex PCR for the detection and differentiation of Vibrio parahaemolyticus strains using the groEL, $t d h$ and trh genes. Mol. Cell Probe. 27, 171-175. doi: 10.1016/j.mcp.2013.04.001

Huff, K., Aroonnual, A., Littlejohn, A. E. F., Rajwa, B., Bae, E., Banada, P. P., et al. (2012). Light-scattering sensor for real-time identification of Vibrio parahaemolyticus, Vibrio vulnificus and Vibrio cholerae colonies on solid agar plate. Microb Biotechnol. 5, 607-620. doi: 10.1111/j.1751-7915.2012.00349.x

Izore, T., Job, V., and Dessen, A. (2011). Biogensis, regulation, an targeting of the type III secretion system. Cell Press 19, 603-612. doi: 10.1016/j.str. 2011. 03.015

Izumiya, H., Matsumoto, K., Yahiro, S., Lee, J., Morita, M., Yamamoto, S., et al. (2011). Multiplex PCR assay for identification of three major pathogenic Vibrio spp., Vibrio cholerae, Vibrio parahaemolyticus, and Vibrio vulnificus. Mol. Cell. Probe 25, 174-176. doi: 10.1016/j.mcp.2011.04.004

Jakabi, M., Gelli, D. S., Torre, J. C. M. D., Rodas, M. A. B., Franco, B. D. G. M., Destro, M. T., et al. (2003). Inactivation by ionizing radiation of Salmonella enteritidis Salmonella infantis, and Vibrio parahaemolyticus in oyster (Crassostrea brasiliana). J. Food Prot. 66, 1025-1029.

Jegga, A. G., Schneider, L., Ouyang, X., and Zhang, J. (2011). Systems biology of the autophagy-lysosomal pathway. Autophagy 7, 477-489. doi: 10.4161/auto.7. 5.14811

Jones, J. L., Lüdeke, C. H., Bowers, J. C., DeRosia-Banick, K., Carey, D. H., and Hastback, W. (2014). Abundance of Vibrio cholerae, V. vulnificus, and V. parahaemolyticus in oysters (Crassostrea virginica) and clams (Mercenaria mercenaria) from Long Island sound. Appl. Environ. Microbiol. 80, 7667-7672. doi 10.1128/AEM.02820-14

Jones, J. L., Ludeke, C. H., Bowers, J. C., Garrett, N., Fischer, M., Parsons, M. B., et al. (2012). Biochemical, serological, and virulence characterization of clinical and oyster Vibrio parahaemolyticus isolates. J. Clin. Microbiol. 50, 2343-2352. doi: 10.1128/JCM.00196-12

Joseph, S., Colwell, R., and Kaper, J. (1982). Vibrio parahaemolyticus and related halophilic Vibrios. Crit. Rev. Microbiol. 10, 77-124. doi: 10.3109/10408418209 113506

Kajino-Sakamoto, R., Inagaki, M., Lippert, E., Akira, S., Robine, S., Matsumoto, K., et al. (2008). Enterocyte-derived TAK1 signaling prevent sepithelium apoptosis and the development of ileitis and colitis. J. Immunol. 181, 1143-1152. doi: 10.4049/jimmunol.181.2.1143

Kauppi, A. M., Nordfelth, R., Uvell, H., Wolf-Watz, H., and Elofsson, M. (2003) Targeting bacterial virulence: inhibitors of type III secretion in Yersinia. Chem. Biol. 10, 241-249. doi: 10.1016/S1074-5521(03)00046-2
Kawatsu, K., Ishibashi, M., and Tsukamoto, T. (2006). Development and evaluation of a rapid, simple, and sensitive immunochromatographic assay to detect thermostable direct hemolysin produced by Vibrio parahaemolyticus in enrichment cultures of stool specimens. J. Clin. Microbiol. 44, 1821-1827. doi: 10.1128/JCM.44.5.1821-1827.2006

Kim, J.-J., and Jo, E.-K. (2013). NLRP3 inflammasome and host protection against bacterial infection. J. Korean Med. Sci. 28, 1415-1423. doi: 10.3346/jkms.2013.28.10.1415

Kodama, T., Rokuda, M., Park, K. S., Cantarelli, V. V., Matsuda, S., Iida, T., et al. (2007). Identification and characterization of Vop T, a novel ADP- ribosyltransferase effector protein secreted via the Vibrio parahaemolyticus type III secretion system 2. Cell Microbiol. 9, 2598-2609. doi: 10.1111/ j.1462-582 2.2007. 00980.x

Kodama, T., Yamazaki, C., Park, K. S., Akeda, Y., Iida, T., and Honda, T. (2010). Transcription of Vibrio parahaemolyticus T3SS1 genes is regulated by a dual regulation system consisting of the ExsACDE regulatory cascade and H-NS. FEMS Microbiol. Lett. 311, 10-17. doi: 10.1111/j.1574-6968.2010.02066.x

Krauss, M., and Haucke, V. (2007). Phosphoinositides: regulators of membrane traffic and protein function. FEBS Lett. 581, 2105-2111. doi: 10.1016/j.febslet.200 7.01 .089

Kumar, B. K., Raghunah, P., Devegowda, D., Deekshit, K., Venugopal, N. V., Karunasagar, I., et al. (2011). Development of monoclonal antibody based sandwich ELISA for the rapid detection of pathogenic Vibrio parahaemolyticus in seafood. Intl. J. Food microbiol. 145, 244-249. doi: 10.1016/j.ijfoodmicro.2010.12.030

Laanto, E., Bamford, J. K. H., Laakso, J., and Sundberg, L. R. (2012). Phagedriven loss of virulence in a fish pathogenic bacterium. PLOS ONE 7:e53157. doi: 10.1371/journal.pone.0053157

Lee, J. K., Jung, D. W., Eom, S. Y., Oh, S. W., Kim, Y. J., Kwak, H. S., et al. (2008). Occurrence of Vibrio parahaemolyticus in oysters from Korean retail outlets. Food Control 19, 990-994. doi: 10.1016/j.foodcont.2007.10.006

Levin, R. E. (2006). Vibrio parahaemolyticus, a notably lethal human pathogen derived from seafood: a review of its pathogenicity, characteristics, subspecies characterization, and molecular methods of detection. Food Biotechnol. 20, 93128. doi: $10.1080 / 08905430500524275$

Letchumanan, V., Chan, K. G., and Lee, L. H. (2014). Vibrio parahaemolyticus: a review on the pathogenesis, prevalence, and advance molecular identification techniques. Front. Microbiol. 5:705. doi: 10.3389/fmicb.2014.00705

Letchumanan, V., Yin, W. F., Lee, L. H., and Chan, K. G. (2015). Prevalence and antimicrobial susceptibility of Vibrio parahaemolyticus isolated from retail shrimps in Malaysia. Front Microbiol 6:33. doi: 10.3389/fmicb.2015.00033

Liu, H. (2003). Analysis of the collective food poisoning events in Shanghai from 1990 to 2000. Chinese J. Nat. Med. 5, 17-20.

Liu, X. M., Chen, Y., Fan, Y. X., and Wang, M. Q. (2006). Foodborne diseases occurred in 2003 report of the National Foodborne Diseases Surveillance system, China. Wei Sheng Yan Jiu 35, 201-204.

Liverman, A. D., Cheng, H. C, Trosky, J. E., Leung, D. W., Yarbrough, M. L., Burdette, D. L., et al. (2007). Arp2/3-independent assembly of actin by Vibrio type III effector Vop L. Proc. Natl. Acad. Sci. U.S.A. 104, 17117-17122. doi: 10.1073/pnas. 0703196104

Lozano-León, A., Torres, J., Osorio, C. R., and Martínez-Urtaza, J. (2003). Identification of tdh-positive Vibrio parahaemolyticus from an outbreak associated with raw oyster consumption in Spain. FEMS Microbiol. Lett. 226, 281-284. doi: 10.1016/S0378-1097(03)00604-9

Luong, P., Kinch, L. N., Brautigam, C. A., Grishin, N. V., Tomchick, D. R., and Orth, K. (2010). Kinetic and structural insights into the mechanism of AMPylation by Vop S Fic domain. J. Biol. Chem. 285, 20155-20163. doi: 10.1074/jbc.M110.114884

Makino, K., Oshima, K., Kurokawa, K., Yokoyama, K., Uda, T., Tagomori, K., et al. (2003). Genome sequence of Vibrio parahaemolyticus: a pathogenic mechanism distinct from that of $\mathrm{V}$ cholerae. Lancet 361, 743-749. doi: 10.1016/S0140-6736(03)12659-1

Martinez-Diaz, S. F., and Hipolito-Morales, A. (2013). Efficacy of phage therapy to prevent mortality during the vibriosis of brine shrimp. Aquaculture 400, 120-124. doi: 10.1016/j.aquaculture.2013.03.007

Martinez-Urtaza, J., Simental, L., Velasco, D., DePaola, A., Ishibashi, M., Nakaguchi, Y., et al. (2005). Pandemic Vibrio parahaemolyticus O3:K6, Europe. Emerg. Infect. Dis. J. 11, 1319-1320. doi: 10.3201/eid1108.050322 
Mateus, C., Costa, C., Silva, Y., Cunha, A., and Almeida, A. (2014). Efficiency of phage cocktails in the inactivation of Vibrio in aquaculture. Aquaculture 424, 167-173. doi: 10.1016/j.aquaculture.2014.01.001

Matlawska-Wasowska, K., Finn, R., Mustel, A., O’Byrne, C. P., Baird, A. W., Coffey, E. T., et al. (2010). The Vibrio parahaemolyticus type III secretion systems manipulate host cell MAPK for critical steps in pathogenesis. BMC Microbiol. 10:329. doi: 10.1186/1471-2180-10-329

Matsuda, S., Kodama, T., Okada, N., Okayama, K., Honda, T., and Iida, T. (2010) Association of Vibrio parahaemolyticus thermostable direct hemolysin with lipid rafts is essential for cytotoxicity but not hemolytic activity. Infect. Immun. 78, 603-610. doi: 10.1128/IAI.00946-09

Matsuda, S., Okada, N., Kodama, T., Honda, T., and Iida, T. (2012). A cytotoxic type III secretion effector of Vibrio parahaemolyticus targets vacuolar $\mathrm{H}^{+}$-ATPase subunit $c$ and ruptures host cell lysosomes. PLoS Pathog. 8:e1002803. doi: 10.1371/journal.ppat.1002803

McCarthy, S. A., DePaola, A., Cook, D. W., Kaysner, C. A., and Hill, W. E. (1999). Evaluation of alkaline phosphatase- and digoxigenin-labelled probes for detection of the thermolabile hemolysin ( $t$ lh) gene of Vibrio parahaemolyticus. Lett. Appl. Microbiol. 28, 66-70. doi: 10.1046/j.1365-2672.1999.00467.x

Meador, C. E., Parsons, M. M., Bopp, C. A., Gerner-Smidt, P., Painter, J. A., and Vora, G. J. (2007). Virulence gene and pandemic group-specific marker profiling of clinical Vibrio parahaemolyticus isolates. J. Clin. Microbiol. 45, 1133-1139. doi: 10.1128/JCM.00042-07

Miyamoto, Y., Kato, T., Obara, Y., Akiyama, S., Takizawa, K., and Yamai, S. (1969). In vitro hemolytic characteristic of Vibrio parahaemolyticus: its close correlation with human pathogenicity. J. Bacteriol. 100, 1147-1149.

Mota, L. J., Sorg, I., and Cornelis, G. R. (2005). Type III secretion: the bacteria-eukaryotic cell express. FEMS Microbiol. Lett. 252, 1-10. doi: 10.1016/j.femsle.2005.08.036

Nair, G. B, Ramamurthy, T., Bhattacharya, S. K., Dutta, B., Takeda, Y., and Sack, D. A. (2007). Global dissemination of Vibrio parahaemolyticus serotype O3:K6 and its serovariants. Clin. Microbiol. Rev. 20, 39-48. doi: 10.1128/CMR. 00025-06

Nakaguchi, Y. (2013). Contamination by Vibrio parahaemolyticus and its virulent strains in seafood marketed in Thailand, Vietnam, Malaysia, and Indonesia. Trop Med. Health 41, 95-102. doi: 10.2149/tmh.2011-06

Namgoong, S., Boczkowska, M., Glista, M. J., Winkelman, J. D., Rebowski, G., Kovar, D. R., et al. (2011). Mechanism of actin filament nucleation by Vibrio VopL and implications for tandem-W domain nucleation. Nat. Struct. Mol. Biol. 18, 1060-1067. doi: 10.1038/nsmb.2109

Negrea, A., Bjur, E., Ygberg, S. E., Elofsson, M., Wolf-Watz, H., and Rhen, M. (2007). Salicylidene acylhydrazides that affect type III protein secretion in Salmonella enterica serovar typhimurium. Antimicrob. Agents Chemother. 51, 2867-2876. doi: 10.1128/AAC.00223-07

Nemoto, J., Sugawara, C., Akahane, K., Hashimoto, K., Kojima, T., Ikedo, M., et al. (2009). Rapid and specific detection of the thermostable direct hemolysin gene in Vibrio parahaemolyticus by loop mediated isothermal amplification. J. Food Prot. 72, 748-754.

Nishibuchi, M., Fasano, A., Russell, R. G., and Kaper, J. B. (1992). Enterotoxigenicity of Vibrio parahaemolyticus with and without genes encoding thermostable direct hemolysin. Infect. Immun. 60, 3539-3545.

Nishibuchi, M., and Kaper, J. B. (1995). Thermostable direct hemolysin gene of Vibrio parahaemolyticus: a virulence gene acquired by a marine bacterium. Infect. Immun. 63, 2093-2099.

Nordstrom, J. L., Vickery, M. C. L., Blackstone, G. M., Murray, S. L., and DePaola, A. (2007). Development of a multiplex real-time PCR assay with an internal amplification control for the detection of total and pathogenic Vibrio parahaemolyticus bacteria in oysters. Appl. Environ. Microbiol. 73, 5840-5847. doi: 10.1128/AEM.00460-07

O’Boyle, N., and Boyd, A. (2014). Manipulation of intestinal epithelial cell function by the cell contact-dependent typeIII secretion systems of Vibrio parahaemolyticus. Front. Cell Infect. Microbiol. 3:114. doi: 10.3389/fcimb.2013.00114

Okada, N., Matsuda, S., Matsuyama, J., Park, K. S., de los Reyes, C., Kogure, K., et al. (2010). Presence of genes for type III secretion system 2 in Vibrio mimicus strains. BMC Microbiol. 10:302. doi: 10.1186/1471-2180-10-302

Ono, T., Kwon-Sam, P., Ueta, M., Iida, T., and Honda, T. (2006). Identification of proteins secreted via Vibrio parahaemolyticus type III secretion system 1. Infect. Immun. 74, 1032-1042. doi: 10.1128/IAI.74.2.1032-1042.2006
Osawa, R., Okitsu, T., Morozumi, H., and Yamai, S. (1996). Occurrence of urease-positive Vibrio parahaemolyticus in Kanagawa, Japan, with specific reference to presence of thermostable direct hemolysin (TDH) and the TDH-related hemolysin genes. Appl. Environ. Microbiol. 62, 725-727.

Paranjpye, R., Hamel, O. S., Stojanovski, A., and Liermann, M. (2012). Genetic diversity of clinical and environmental Vibrio parahaemolyticus strains from the Pacific Northwest. Appl. Environ. Microbiol. 78, 8631-8638. doi: 10.1128/AEM.01531-12

Park, K. S., Ono, T., Rokuda, K., Jang, M. H., Okada, K., Iida, T., et al. (2004a). Functional characterization of two type III secretion systems of Vibrio parahaemolyticus. Infect. Immun. 72, 6659-6665. doi: 10.1128/IAI.72.11.66596665.2004

Park, K. S., Ono, T., Rokuda, M., Jang, M. H., Iida, T., and Honda, T. (2004b). Cytotoxicity and enterotoxicity of the thermostable direct hemolysin-deletion mutants of Vibrio parahaemolyticus. Microbiol. Immunol. 48, 313-318. doi: 10.1111/j.13480421

Park, K. S., Ono, T., Rokuda, M., Jang, M. H., Okada, K., Iida, T., et al. (2004c). Functional characterization of two III secretion systems of Vibrio parahaemolyticus. Infect. Immun. 72, 6659-6665. doi: 10.1128/IAI.72.11.6659-6665.2004

Pasqualinà, L., Gabriella, C., Eleonora, M., Renata, Z., and Santi, D. (2011). Susceptibility to antibiotics of Vibrio spp. and Photobacterium damselae ssp. piscicida strains isolated from Italian aquaculture farms. New Microbiol. 34, 53-63.

Peng, F. M., Jiang, D. Y., Ruan, H. H., Liu, H. Q., and Zhou, L. P. (2010). Pathogenic investigation on a food poisoning induced by Vibrio parahaemolyticus. Prev. Med. Trib. 16, 746-747.

Peng, L., Chen, B. W., Luo, Y. A., and Wang, G. Z. (2006). Effect of mycobacteriophage to intracellular mycobateria in vitro. Chin. Med. J. 119, 692-695.

Porta, H., Cancino-Rodezno, A., Soberon, M., and Bravo, A. (2011). Role of MAPK p38 in the cellular responses to pore-forming toxins. Peptides 32, 601-606. doi: 10.1016/j.peptides. 2010.06.012

Prochazkova, K., and Satchell, K. J. (2008). Structure-function analysis of inositol hexakisphosphate-induced auto processing of the Vibrio cholerae multifunctional auto processing RTX toxin. J. Biol. Chem. 283, 23656-23664. doi: 10.1074/jbc.M803334200

Prompamorn, P., Longyant, S., Pengsuk, C., Sithigorngul, P., and Chaivisuthangkura, P. (2013). Rapid identification and differentiation of Vibrio parahaemolyticus from Vibrio spp. in seafood samples using developed monoclonal antibodies. World J. Microbiol. Biotechnol. 29, 721-731. doi: 10.1007/s11274-0121228-6

Pruitt, R. N., Chagot, B., Cover, M., Chazin, W. J., Spiller, B., and Lacy, D. B. (2009). Structure function analysis of inositol hexakisphosphate-induced auto processing in Clostridium difficile toxin A. J. Biol. Chem. 284, 21934-21940. doi: 10.1074/jbc.M109.018929

Pukatzki, S., Ma, A. T., Revel, A. T., Sturtevant, D., and Mekalanos, J. J. (2007). Type VI secretion system translocates a phage tail spike-like protein into target cells where it cross-links actin. Proc. Natl. Acad. Sci. U.S.A. 104, 15508-15513. doi: 10.1073/pnas.0706532104

Pukatzki, S., Ma, A. T., Sturtevant, D., Krastins, B., Sarracino, D., Nelson, W. C., et al. (2006). Identification of a conserved bacterial protein secretion system in Vibrio cholerae using the Dictyostelium host model system. Proc. Natl. Acad. Sci. U.S.A. 103, 1528-1533. doi: 10.1073/pnas.0510322103

Qi, J., Du, Y., Zhu, R., Zhu, X., Bai, H., Hu, M., et al. (2012). A loop-mediated isothermal amplification method for rapid detection of the multidrug-resistance gene cfr. Gene 504, 140-143. doi: 10.1016/j.gene.2012.04.049

Raghunath, P., Karunasagar, I., and Karunasagar, I. (2009). Improved isolation and detection of pathogenic Vibrio parahaemolyticus from seafood using a new enrichment broth. Int. J. Food Microbiol. 129, 200-203. doi: 10.1016/j.ijfoodmicro.2008.11.026

Rahimi, E., Ameri, M., Doosti, A., and Gholampour, A. R. (2010). Occurrence of toxigenic Vibrio parahaemolyticus strains in shrimp in Iran. Foodborne Pathog. Dis. 7, 1107-1111. doi: 10.1089/fpd.2010.0554

Ren, T., and Su, Y. C. (2006). Effects of electrolyzed oxidizing water treatment on reducing Vibrio parahaemolyticus and Vibrio vulnificus in raw oysters. J. Food Prot. 69, 1829-1834.

Ritchie, J. M., Rui, H., Bronson, R. T., and Waldor, M. K. (2010). Back to the future: studying cholera pathogenesis using infant rabbits. mBio 1:e00047-10. doi:10.1128/mBio.00047-10 
Ritchie, J. M., Rui, H., Zhou, X., Iida, T., Kodoma, T., Ito, S., et al. (2012). Inflammation and disintegration of intestinal villi in an experimental model for Vibrio parahaemolyticus induced diarrhea. PLoS Pathog 8:e1002593. doi: 10.1371/journal.ppat.1002593

Robert-Pillot, A., Copin, S., Gay, M., Malle, P., and Quilici, M. L. (2010). Total and pathogenic Vibrio parahaemolyticus in shrimp: fast and reliable quantification by real-time PCR. Int. J. Food Microbiol. 143, 190-197. doi 10.1016/j.ijfoodmicro.2010.08.016

Rosec, J. P., Simon, M., Causse, V., and Boudjemaa, M. (2009). Detection of total and pathogenic Vibrio parahaemolyticus in shellfish: comparison of PCR protocols using pR72H or toxR targets with a culture method. Int. J. Food Microbiol. 129, 136-145. doi: 10.1016/j.ijfoodmicro.2008.11.017

Sakata, J., Kawatsu, K., Kawahara, R., Kanki, M., Iwasaki, T., Kumeda, Y., et al. (2012). Production and characterization of a monoclonal antibody agains recombinant thermolabile hemolysin and its application to screen for Vibrio parahaemolyticus contamination in raw seafood. Food Control 23, 171-176. doi: 10.1016/j.foodcont.2011.07.005

Sakazaki, R., Tamura, K., Kato, T., Obara, Y., and Yamai, S. (1968). Studies on the enteropathogenic, facultatively halophilic bacterium, Vibrio parahaemolyticus. 3. Enteropathogenicity. Jpn. J. Med. Sci. Biol. 21, 325-331. doi: 10.7883/yoken1952.21.325

Salomon, D., Guo, Y. R., Kinch, L. N., Grishin, N. V., Gardner, K. H., and Orth, K. (2013a). Effectors of animal and plant pathogens use a common domain to bind host phosphoinositides. Nat. commun. 4:2973. doi: 10.1038/ncomms3973

Salomon, D., Gonzalez, H., Updegraff, B. L., and Orth, K. (2013b). Vibrio parahaemolyticus type VI secretion system 1 is activated in marine conditions to target bacteria, and is differentially regulated from system 2. PLOS ONE 8:e61086. doi: 10.1371/journal.pone.0061086

Salomon, D., Kinch, L. N., Trudgian, D. C., Guo, X. F., Klimko, J. A., Grishin, N. V., et al. (2014). Marker for type VI secretion system effectors. Proc. Natl. Acad. Sci. U.S.A. 111, 9271-9276. doi: 10.1073/pnas.1406110111

Shimohata, T., Nakano, M., Lian, X., Shigeyama, T., Iba, H., Hamamoto, A., et al. (2011). Vibrio parahaemolyticus infection induces modulation of IL-8 secretion through dual pathway via VP1680 in Caco-2 cells. J. Infect. Dis. 203, 537-544. doi: 10.1093/infdis/jiq070

Shimohata, T., and Takahashi, A. (2010). Diarrhea induced by infection of Vibrio parahaemolyticus. J. Med. Invest. 57, 179-182. doi: 10.2152/jmi.57.179

Shinoda, S., Matsuoka, H., Tsuchie, T., Miyoshi, S., Yamamoto, S., Taniguchi, H., et al. (1991). Purification and characterization of a lecithin-dependent haemolysin from Escherichia coli transformed by a Vibrio parahaemolyticus gene. J. Gen. Microbiol. 137, 2705-2711. doi: 10.1099/00221287-137-12-2705

Shivu, M. M., Rajeeva, B. C., Girisha, S. K., Karunasagar, I., Krohne, G., and Karunasagar, I. (2007). Molecular characterization of Vibrio harveyi bacteriophages isolated from aquaculture environments along the coast of India. Environ. Microbiol. 9, 322-331. doi: 10.1111/j.1462-2920.2006.01140.x

Shneider, M. M., Buth, S. A., Ho, B. T., Basler, M., Mekalanos, J. J., and Leiman, P. G. (2013). PAAR-repeat proteins sharpen and diversify the type VI secretion system spike. Nature 500, 350-353. doi: 10.1038/nature12453

Silva, Y. J., Costa, L., Pereira, C., Cunha, A., Calado, R., Gomes, N. C., et al. (2014a). Influence of environmental variables in the efficiency of phage therapy in aquaculture. Microb. Biotechnol. 7, 401-413. doi: 10.1111/1751-7915. 12090

Silva, Y. J., Costa, L. L., Pereira, C., Mateus, C., Cunha, A., Calado, R., et al. (2014b). Phage therapy as an approach to prevent Vibrio anguillarum infections in fish larvae production. PLOS ONE 9:e114197. doi: 10.1371/journal.pone. 0114197

Sreelatha, A., Bennett, T. L., Zheng, H., Jiang, Q. X., Orth, K., and Starai, V. J. (2013). Vibrio effector protein, Vop Q, forms a lysosomal gated channel that disrupts host ion homeostasis and autophagic flux. Proc. Natl. Acad. Sci. U.S.A. 110, 11559-11564. doi: 10.1073/pnas.1307032110

Su, Y. C., Duan, J., and Wu, W. H. (2005). Selectivity and specificity of a chromogenic medium for detecting Vibrio parahaemolyticus. J. Food Prot. 68, 1454-1456.

Su, Y. C., and Liu, C. C. (2007). Vibrio parahaemolyticus: a concern of seafood safety. Food microbiol. 24, 549-558. doi: 10.1016/j.fm.2007.01.005

Sun, P., Tropea, J. E., Austin, B. P., Cherry, S., and Waugh, D. S. (2008). Structural characterization of the Yersinia pestis type III secretion needle protein YscF in complex with its heterodimeric chaperone YscE/YscG. J. Mol. Biol. 377, 819-830. doi: 10.1016/j.jmb.2007.12.067
Takahashi, A., Kenjyo, N., Imura, K., Myonsun, Y., and Honda, T. (2000). Cl- secretion in colonic epithelial cells induced by the Vibrio parahaemolyticus hemolytic Toxin related to thermostable direct hemolysin. Infect. Immun. 68, 5435-5438. doi: 10.1128/IAI.68.9.5435-5438.2000

Tamano, K. (2000). Supra molecular structure of the Shigella type III secretion machinery: the needle part is changeable in length and essential for delivery of effectors. EMBO J. 19, 3876-3887. doi: 10.1093/emboj/19. 15.3876

Tan, D., Gram, L., and Middelboe, M. (2014). Vibriophages and their interactions with the fish pathogen Vibrio anguillarum. Appl. Environ. Microbiol. 80, 31283140. doi: 10.1128/AEM.03544-3513

Tran, L., Nunan, L., Redman, R. M., Mohney, L. L., Pantoja, C. R., Fitzsimmons, K., et al. (2013). Determination of the infectious nature of the agent of acute hepatopancreatic necrosis syndrome affecting penaeid shrimp. Dis. Aquat. Organ. 105, 45-55. doi: 10.3354/dao02621

Trosky, J. E., Mukherjee, S., Burdette, D. L., Roberts, M., Mccarter, L., Siegel, R. M., et al. (2004). Inhibition of MAPK signaling pathways by Vop A from Vibrio parahaemolyticus. J. Biol. Chem. 279, 51953-51957. doi: 10.1074/jbc. M4070012 00

Tyagi, A., Saravanan, V., Karunasagar, I., and Karunasagar, I. (2009). Detection of Vibrio parahaemolyticus in tropical shellfish by SYBR green real-time PCR and evaluation of three enrichment media. Int. J. Food Microbiol. 129, 124-130. doi: 10.1016/j.ijfoodmicro.2008.11.006

Veenendaal, A. K. J., Sundin, C., and Blocker, A. J. (2009). Small-molecule type III secretion system inhibitors block assembly of the Shigella type III secreton. J. Bacteriol. 191, 563-570. doi: 10.1128/JB.01004-08

Wang, R. Z., Huang, J. D., Zhang, W., Lin, G. M., Lian, J. W., Jiang, L. B., et al. (2011a). Detection and identification of Vibrio parahaemolyticus by multiplex PCR and DNA-DNA hybridization on a microarray. J. Genet. Genomics 38, 129-135. doi: 10.1016/j.jgg.2011.02.002

Wang, H. P., Zhang, J. L., Jiang, T., Bao, Y. X., and Zhou, X. M. (2011b). Insufficiency of the Kanagawa hemolytic test for detecting pathogenic Vibrio parahaemolyticus in Shanghai, China. Diagn. Microbiol. Infect. Dis. 69, 7-11. doi: 10.1016/j.diagmicrobio.2010.08.016

Wang, L., Shi, L., Su, J. Y., Ye, Y. X., and Zhong, Q. P. (2013a). Detection of Vibrio parahaemolyticus in food samples using in situ loop-mediated isothermal amplification method. Gene 515, 421-425. doi: 10.1016/j.gene.2012. 12.039

Wang, R. Z., Xiang, S. S., Feng, Y. J., Srinivas, S., Zhang, Y. F., Lin, M. S., et al. (2013b). Engineering production of functional scFv antibody in E. coli by coexpressing the molecule chaperone Skp. Front. Cell Infect. Microbiol. 3:72. doi: 10.3389/fcimb.2013.00072

Wang, R. Z., Fang, S., Wu, D. L., Wu, D., Lian, J., Fan, J., et al. (2012). Screening of a ScFv antibody that can neutralize effectively the cytotoxicity of Vibrio parahaemolyticus TLH. Appl. Environ. Microbiol. 78, 4967-4975. doi: 10.1128/AEM.00435-12

Wang, R. Z., Xiang, S. S., Zhang, Y. H., Chen, Q. Y., Zhong, Y. F., and Wang, S. H. (2014a). Development of a functional antibody by using a green fluorescent protein frame as the template. Appl. Environ. Microbiol. 80, 4126-4137. doi: 10.1128/AEM.00936-14

Wang, R. Z., Fang, S., Xiang, S. S., Ling, S. M., Yuan, J., and Wang, S. H. (2014b). Generation and Characterization of a scFv Antibody Against T3SS Needle of Vibrio parahaemolyticus. Indian J. Microbiol. 54, 143-150. doi: 10.1007/s12088013-0428-426

Ward, L. N., and Bej, A. K. (2006). Detection of Vibrio parahaemolyticus in shellfish by use of multiplexed real-time PCR with TaqMan fluorescent probes. Appl. Environ. Microbiol. 72, 2031-2042. doi: 10.1128/AEM.72.3.2031-2042.2006

Worrall, L. J., Lameignere, E., and Strynadka, N. C. (2011). Structural overview of the bacterial injectisome. Curr. Opin. Microbiol. 14, 3-8. doi: 10.1016/j.mib.2010.10.009

Xiang, G. M., Pu, X. Y., Jiang, D. N., Liu, L. L., Liu, C., and Liu, X. B. (2013). Development of a real-time resistance measurement for Vibrio parahaemolyticus detection by the Lecithin-Dependent hemolysin gene. PLoS ONE 8:e72342. doi: 10.1371/journal.pone.0072342

Xu, X. K., Wu, Q. P., Zhang, J. M., Cheng, J. H., Zhang, S. H., and Wu, K. (2014). Prevalence, pathogenicity, and serotypes of Vibrio parahaemolyticus in shrimp from Chinese retail markets. Food Control 46, 81-85. doi: 10.1016/j.foodcont.2014.04.042 
Yamazaki, W., Ishibashi, M., Kawahara, R., and Inoue, K. (2008). Development of a loopmediated isothermal amplification assay for sensitive and rapid detection of Vibrio parahaemolyticus. BMC Microbiol. 8:163. doi: 10.1186/1471-2180-8-163

Yarbrough, M. L., Li, Y., Kinch, L. N., Grishin, N. V., Ball, H. L., and Orth, K. (2009). AMPylation of RhoGTPases by Vibrio Vop S disrupts effector binding and downstream signaling. Science 323, 269-272. doi: 10.1126/science.1166382

Yeung, P. S., and Boor, K. J. (2004). Epidemiology, pathogenesis, and prevention of foodborne Vibrio parahaemolyticus infections. Foodborne Pathog. Dis. 1, 74-88. doi: 10.1089/153531404323143594

Yu, B., Cheng, H.-C., Brautigam, C. A., Tomchick, D. R., and Rosen, M. K. (2011). Mechanism of actin filament nucleation by the bacterial effector VopL. Nat. Struct. Mol. Biol. 18, 1068-1074. doi: 10.1038/nsmb.2110

Yu, Y., Yang, H., Li, J., Zhang, P., Wu, B., Zhu, B., et al. (2012). Putative type VI secretion systems of Vibrio parahaemolyticus contribute to adhesion to cultured cell monolayers. Arch. Microbiol. 194, 827-835. doi: 10.1007/s00203-012-0816-Z

Zeng, J., Wei, H. Y., Zhang, L., Liu, X. F., Zhang, H. Y., Cheng, J. X., et al. (2014). Rapid detection of Vibrio parahaemolyticus in raw oysters using immunomagnetic separation combined with loop-mediated isothermal amplification. Int. J. Food Microbiol. 174, 123-128. doi: 10.1016/j.ijfoodmicro.2014.01.004

Zhang, L., Krachler, A. M., Broberg, C. A., Li, Y., Mirzaei, H., Gilpin, C. J., et al. (2012). Type III effector Vop C mediates invasion for Vibrio species. Cell Rep. 1, 453-460. doi: 10.1016/j.celrep.2012.04.004

Zhang, L. L., and Orth, K. (2013). Virulence determinants for Vibrio parahaemolyticus infection. Curr. Opin. Microbiol. 16, 1-8. doi: 10.1016/j.mib.2013.02.002

Zhang, X. H., and Austin, B. (2005). Haemolysins in Vibrio species. J. Appl. Microbiol. 98, 1011-1019. doi: 10.1111/j.1365-2672.2005.02583.x

Zhao, X., Li, Y., Wang, L., You, L., Xu, Z., Li, L., et al. (2011). Development and application of a loop-mediated isothermal amplification method on rapid detection of Pseudomonas aeruginosa strains. World J. Microbiol. Biotechnol. 27, 181-184. doi: $10.1007 /$ s11274-010-0429-0
Zhou, X., Gewurz, B. E., Ritchie, J. M., Takasaki, K., Greenfeld, H., Kieff, E., et al. (2013). A Vibrio parahaemolyticus T3SS effector mediates pathogenesis by independently enabling intestinal colonization and inhibiting TAK1 activation. Cell Rep. 3, 1690-1702. doi: 10.1016/j.celrep. 2013.03.039

Zhou, X., Konkel, M. E., and Call, D. R. (2010). Regulation of type III secretion system 1 gene expression in Vibrio parahaemolyticus is dependent on interactions between ExsA, ExsC, and ExsD. Virulence 1, 260-272. doi: 10.4161/viru.1.4. 12318

Zhu, R. G., Li, T. P., Jia, Y. F., and Song, L. F. (2012). Quantitative study of viable Vibrio parahaemolyticus cells in raw seafood using propidium monoazide in combination with quantitative PCR. J. Microbiol. Methods 90, 262-266. doi: 10.1016/j.mimet.2012.05.019

Conflict of Interest Statement: The authors declare that the research was conducted in the absence of any commercial or financial relationships that could be construed as a potential conflict of interest.

Received: 14 January 2015; accepted: 07 February 2015; published online: 05 March 2015.

Citation: Wang R, Zhong Y, Gu X, Yuan J, Saeed AF and Wang S (2015) The pathogenesis, detection, and prevention of Vibrio parahaemolyticus. Front. Microbiol. 6:144. doi: 10.3389/fmicb.2015.00144

This article was submitted to Food Microbiology, a section of the journal Frontiers in Microbiology.

Copyright (c) 2015 Wang, Zhong, Gu, Yuan, Saeed and Wang. This is an openaccess article distributed under the terms of the Creative Commons Attribution License (CC BY). The use, distribution or reproduction in other forums is permitted, provided the original author(s) or licensor are credited and that the original publication in this journal is cited, in accordance with accepted academic practice. No use, distribution or reproduction is permitted which does not comply with these terms. 